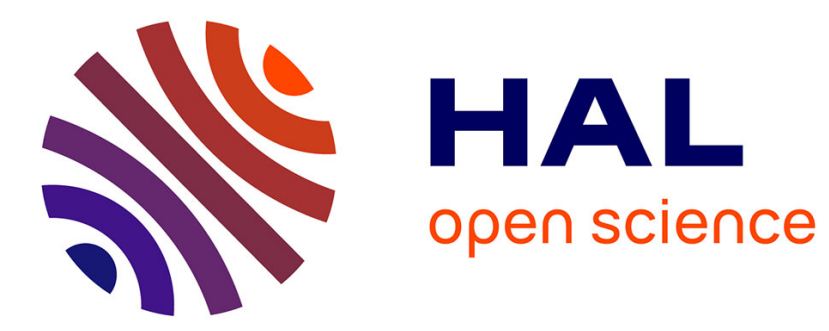

\title{
Synthesis and structural variety of first Mn and Bi selenites and selenite chlorides
}

\author{
Olivier Mentré
}

\section{To cite this version:}

Olivier Mentré. Synthesis and structural variety of first Mn and Bi selenites and selenite chlorides. Zeitschrift für Kristallographie - Crystalline Materials, 2019, 234 (3), pp.141-153. 10.1515/zkri-20182088. hal-03098311

\section{HAL Id: hal-03098311 https://hal.science/hal-03098311}

Submitted on 5 Jan 2021

HAL is a multi-disciplinary open access archive for the deposit and dissemination of scientific research documents, whether they are published or not. The documents may come from teaching and research institutions in France or abroad, or from public or private research centers.
L'archive ouverte pluridisciplinaire HAL, est destinée au dépôt et à la diffusion de documents scientifiques de niveau recherche, publiés ou non, émanant des établissements d'enseignement et de recherche français ou étrangers, des laboratoires publics ou privés. 
Vadim M. Kovrugin*, Marie Colmont, Oleg I. Siidra, Dmitry O. Charkin, Almaz Aliev, Sergey V. Krivovichev and Olivier Mentré

\section{Synthesis and structural variety of first $\mathrm{Mn}$ and $\mathrm{Bi}$ selenites and selenite chlorides}

https://doi.org/10.1515/zkri-2018-2088

Received April 19, 2018; accepted October 2, 2018; published online October 16, 2018

Abstract: Single crystals of new $\mathrm{Mn}_{2}\left[\mathrm{Bi}_{2} \mathrm{O}\right]\left(\mathrm{SeO}_{3}\right)_{4}$ (I), $\mathrm{MnBi}\left(\mathrm{SeO}_{3}\right)_{2} \mathrm{Cl}$ (II), $\mathrm{Mn}^{\mathrm{II}} \mathrm{Mn}^{\mathrm{III}}\left(\mathrm{SeO}_{3}\right)_{2} \mathrm{Cl}$ (III), $\mathrm{Mn}_{5}\left(\mathrm{SeO}_{3}\right)_{2} \mathrm{Cl}_{6}$ (IV), and $\mathrm{Mn}_{4}\left(\mathrm{Mn}_{5}, \mathrm{Bi}\right)\left(\mathrm{SeO}_{3}\right)_{8} \mathrm{Cl}_{5}(\mathbf{V})$ have been synthesized by chemical vapour transport and hydrothermal methods. They have been structurally characterized by single crystal X-ray diffraction analysis. The compounds II-V are the first Mn selenite chlorides, while the I, II and $\mathbf{V}$ compounds are the first Bi-containing Mn oxoselenites. Structural relationships of the new phases with other compounds are discussed. An overview of the mixed-ligand $\mathrm{MnO}_{m} \mathrm{Cl}_{n}$ polyhedra in inorganic compounds is given.

Keywords: bismuth; crystal structure; manganese; mixedligand coordination; selenites; single crystal XRD.

\section{Introduction}

Over the last two decades, the chemistry of selenites $\left(\mathrm{Se}^{\mathrm{IV}}\right)$ and selenates $\left(\mathrm{Se}^{\mathrm{VI}}\right)$ has been intensively developed [1-5]. Metal oxyhalides with selenite anions demonstrate a rich and diverse crystal chemistry due to the interplay between soft-soft and hard-hard interactions involving selenite

*Corresponding author: Vadim M. Kovrugin, Department of Crystallography, St. Petersburg State University, 199034 St. Petersburg, Russian Federation; and Unité de Catalyse et Chimie du Solide (UCCS), UMR 8181 CNRS, Université Lille 1 Sciences et Technologies, 59655 Villeneuve d’ASCQ, France,

E-mail: kovrugin_vm@hotmail.com

Marie Colmont, Almaz Aliev and Olivier Mentré: Unité de Catalyse et Chimie du Solide (UCCS), UMR 8181 CNRS, Université Lille 1 Sciences et Technologies, 59655 Villeneuve d'ASCQ, France

Oleg I. Siidra: Department of Crystallography, St. Petersburg State University, 199034 St. Petersburg, Russian Federation; and Nanomaterials Research Center, Kola Science Center, Russian Academy of Sciences, 184200 Apatity, Russian Federation Dmitry O. Charkin: Inorganic Chemistry Division, Department of Chemistry, Moscow State University, GSP-1, 119991 Moscow, Russian Federation

Sergey V. Krivovichev: Department of Crystallography, St. Petersburg State University, 199034 St. Petersburg, Russian Federation; and Kola Science Center, Russian Academy of Sciences, 184209 Apatity, Russian Federation groups, metals and halide ions [6-12]. Note, that the crystal structures of most of them consist of $\mathrm{Cu}$ cations. This fascinating family of versatile structural architectures of selenite halides has been recently reviewed by Berdonosov in Ref. [6]. For several phases, magnetic properties have been studied [13-16]. For example, a series of well-studied francisite-type $\mathrm{Cu}_{3} M\left(\mathrm{SeO}_{3}\right)_{2} \mathrm{O}_{2} X(M=\mathrm{Bi}$, La, $\mathrm{Sm}, \mathrm{Yb} ; X=\mathrm{Cl}, \mathrm{Br}$ ) compounds demonstrates various magnetic behavior depending on $M$ and $X$ ions [17-24]. Also relevant is the crystal chemistry of $\left(\mathrm{SeO}_{3}\right)^{2-}$ groups, which have been recently shown to be similar to those of $\left(\mathrm{HPO}_{3}\right)^{2-}$ phosphite groups, where $\mathrm{H}^{\delta-}$ can substitute the electron lone pair of the selenites [25].

In that frame, $\mathrm{Bi}^{\mathrm{III}}$ ions are of special interest, since they have a strong affinity to specific oxocentered topologies [26-29], and therefore its combination with asymmetric selenite groups may result in unique non-centrosymmetric structural architectures [7, 30,31] with non-linear optical properties of respective materials. For example, the second-harmonic generation ( $\mathrm{SHG}$ ) efficiency of $\mathrm{Bi}\left(\mathrm{SeO}_{3}\right) \mathrm{F}$ exhibiting the largest SHG response among all reported oxoselenites [30] compares well to that of $\mathrm{BiO}\left(\mathrm{IO}_{3}\right)$ (SHG efficiency: $12.5 \times \mathrm{KDP})$; the unique $\beta-\mathrm{Bi}\left(\mathrm{SeO}_{3}\right) \mathrm{Cl}$ with a giant ( $V=19792 \AA^{3}$ ) unit cell (SHG efficiency: $2 \times \mathrm{KDP}$ ) possesses an exceptionally complex structure [7].

Incorporation of transition metals into the crystal structures of bismuth selenite oxyhalides sometimes results in unusual physical properties. In particular, the Fe-containing $\mathrm{Bi}_{2} \mathrm{Fe}\left(\mathrm{SeO}_{3}\right)_{2} \mathrm{OCl}_{3}$ material is an interesting example of the quasi-one-dimensional magnetic system [16]. We have been encouraged to explore the manganesecontaining bismuth selenite-oxychloride system, which has never been reported yet. Here, unconventional magnetoelectric properties motivated us, since the mixed valence halide-free $\left[\mathrm{Mn}_{3+\mathrm{x}} \mathrm{O}_{7}\right]\left[\mathrm{Bi}_{4} \mathrm{O}_{4.5-\mathrm{y}}\right]$ phase with a mapleleaf lattice is an unusual 2D antiferromagnet [32], while the well-known multiferroic $\mathrm{BiMnO}_{3}$ shows a complex magnetic phase diagram [33].

In order to fill this gap, we report on the syntheses and structural characterization of five novel phases, namely, $\mathrm{Mn}_{2}{ }_{2}^{\mathrm{II}}\left[\mathrm{Bi}_{2} \mathrm{O}\right]\left(\mathrm{SeO}_{3}\right)_{4}(\mathrm{I}), \mathrm{Mn}^{\mathrm{II}} \mathrm{Bi}\left(\mathrm{SeO}_{3}\right)_{2} \mathrm{Cl}$ (II), $\mathrm{Mn}^{\mathrm{II}} \mathrm{Mn}^{\mathrm{III}}\left(\mathrm{SeO}_{3}\right)_{2} \mathrm{Cl}$ (III), $\mathrm{Mn}_{5}{ }_{5}^{\mathrm{II}}\left(\mathrm{SeO}_{3}\right)_{2} \mathrm{Cl}_{6}$ (IV), and $\mathrm{Mn}_{4}{ }_{4}\left(\mathrm{Mn}_{5} \mathrm{II}, \mathrm{Bi}\right)\left(\mathrm{SeO}_{3}\right)_{8} \mathrm{Cl}_{5}(\mathbf{V})$. The compounds III and IV are the first Mn selenite chlorides without alien cations; while 
the compounds I, II and $\mathbf{V}$ are the first examples of $\mathrm{Mn}-\mathrm{Bi}$ selenites and selenite-chlorides. Structural relationships of the new classes of materials with other compounds will also be discussed.

\section{Experimental}

\section{Synthesis}

New compounds reported in this work have been synthesized by two different methods.

The $\mathrm{Mn}_{2}\left[\mathrm{Bi}_{2} \mathrm{O}\right]\left(\mathrm{SeO}_{3}\right)_{4}$ (I) compound has been obtained from the hydrothermal reaction of $\mathrm{SeO}_{2}$ (2.5 mmol), $\mathrm{MnO}_{2}$ (2.0 mmol), $\mathrm{Mn}_{2} \mathrm{O}_{3}$ $(0.25 \mathrm{mmol})$, and $\mathrm{BiOCl}(3.0 \mathrm{mmol})$ carried out in $6 \mathrm{~mL}$ of distilled water. The reaction was run in a $23 \mathrm{~mL}$ Parr hydrothermal autoclave at $200^{\circ} \mathrm{C}$ for 2 days and the autoclave was slowly cooled to room temperature at a rate of $3.7^{\circ} \mathrm{C} / \mathrm{h}$. The resulting precipitate was filtered through a filter paper. Transparent brownish single crystals of I were found in association with dark brown single crystals of $\mathrm{Mn}_{3} \mathrm{O}\left(\mathrm{SeO}_{3}\right)_{3}[34]$ in white powder of mixed $\mathrm{Bi}_{2}\left(\mathrm{SeO}_{3}\right)_{3}[35]$ and $\mathrm{BiOCl}$ [36] composition.

The other phases have been prepared using the chemical vapour transport (CVT) method, which has already demonstrated its efficiency for the synthesis of novel selenium-based oxyhalides $[8,37]$. Interestingly, the new $\mathrm{MnBi}\left(\mathrm{SeO}_{3}\right)_{2} \mathrm{Cl}(\mathrm{II}), \mathrm{Mn}^{\mathrm{II}} \mathrm{Mn}^{\mathrm{II}}\left(\mathrm{SeO}_{3}\right)_{2} \mathrm{Cl}$ (III), and $\mathrm{Mn}_{4}\left(\mathrm{Mn}_{5}, \mathrm{Bi}\right)\left(\mathrm{SeO}_{3}\right)_{8} \mathrm{Cl}_{5}(\mathrm{~V})$ phases were grown as a result of the CVT reaction of precursors mixed in the same molar ratio as the following: $\mathrm{SeO}_{2}(4.0 \mathrm{mmol}), \mathrm{Mn}_{2} \mathrm{O}_{3}(1.0 \mathrm{mmol}), \mathrm{Bi}_{2} \mathrm{O}_{3}(1.0 \mathrm{mmol})$ and $\mathrm{BiCl}_{3}(2.0 \mathrm{mmol}) . \mathrm{Mn}_{5}\left(\mathrm{SeO}_{3}\right)_{2} \mathrm{Cl}_{6}$ (IV) was obtained from the mixture of $\mathrm{Bi}_{2}\left(\mathrm{SeO}_{3}\right)_{3}: \mathrm{MnCl}_{2}=1: 1$. The mixtures of precursors were loaded into glass tubes $(15 \times 0.9 \mathrm{~cm})$, which were evacuated $\left(10^{-2} \mathrm{mbar}\right)$ and sealed. The tubes were placed horizontally in a tubular furnace so that the precursor-filled ('hot') zone was situated in the central part of the furnace, while the opposite precursor-free ('deposition') zone was turned out toward the furnace edge. This edge remained uncapped during the experiment to create a temperature gradient of about $50^{\circ} \mathrm{C}$ between the two zones of the tubes. Different thermal treatment programs were applied for the preparation of the new compounds as listed in Table 1. The furnace was switched off after slow cooling to $200^{\circ} \mathrm{C}$. At the end of reactions, brown single crystals of II-V were observed in association with single crystals of additional phases in the deposition zones of the tubes. It is worthy to note that the crystal growth of the new phases shows a strong dependence on the temperature conditions of the syntheses.

In order to prepare pure bulk polycrystalline samples of the new compounds, we tried to increase the duration of thermal treatment.
It resulted in preparation of pure phases with maximum yield of approximately $60 \%$ based on hydrated $\mathrm{MnCl}_{2}$ for the compound IV with optimal heating time of $216 \mathrm{~h}$.

\section{Single crystal X-ray diffraction}

Single crystals of new compounds were mounted on thin glass fibers for X-ray diffraction (XRD) analysis and tested using a Bruker DUO APEX II CCD four-circle diffractometer with a $\mathrm{I} u \mathrm{~S}$ micro-focus tube delivering a $\mathrm{MoK}_{\alpha}$ radiation, $\lambda=0.71073 \AA$ at $50 \mathrm{kV}$ and $40 \mathrm{~mA}$. More than a hemisphere of three-dimensional XRD data was collected for each compound with frame widths of $0.5^{\circ}$ in $\omega$, and a $30 \mathrm{~s}$ count time for each frame. The diffraction data were integrated and corrected for absorption using a multi-scan type model integrated in the APEX2 and SADABS Bruker programs. The unit cell parameters were determined and refined by least-squares techniques. The crystal structures of $\mathrm{Mn}_{2}\left[\mathrm{Bi}_{2} \mathrm{O}\right]$ $\left(\mathrm{SeO}_{3}\right)_{4}(\mathrm{I}), \mathrm{MnBi}\left(\mathrm{SeO}_{3}\right)_{2} \mathrm{Cl}(\mathrm{II}), \mathrm{Mn}^{\mathrm{II}} \mathrm{Mn}^{\mathrm{III}}\left(\mathrm{SeO}_{3}\right)_{2} \mathrm{Cl}$ (III), $\mathrm{Mn}_{5}{ }_{5}\left(\mathrm{SeO}_{3}\right)_{2} \mathrm{Cl}_{6}$ (IV), and $\mathrm{Mn}_{4}\left(\mathrm{Mn}_{5}, \mathrm{Bi}\right)\left(\mathrm{SeO}_{3}\right)_{8} \mathrm{Cl}_{5}(\mathbf{V})$ were solved by direct methods using the SHELXL-2013 program [39] and refined to the agreement factors $\left(R_{1}[I>2 \sigma(I)]\right)$ of $2.9 \%, 2.1 \%, 4.9 \%, 2.8 \%$, and $2.2 \%$, respectively.

The final structural models include coordinates and anisotropic displacement parameters for all atoms. Data collection refinement parameters and detailed crystallographic information are provided in Table 2. Fractional atomic coordinates, atomic displacement parameters, and selected bond distances are listed in Tables S1-S5, S6-S10, and S11-S15, respectively. The results of the bond-valence sum (BVS) analysis are given in Tables S16-S20. Empirical bond valence parameters required for the BVS calculations for Mn and Se were taken from Ref. [40] and for Bi from Ref. [41]. Further details of the crystal structure investigations may be obtained from FIZ Karlsruhe (crysdata@fiz-karlsruhe.de) on quoting the deposition numbers CSD-434425, CSD-434426, CSD-434427, CSD-434428, and CSD-424429 for $\mathrm{Mn}_{2}\left[\mathrm{Bi}_{2} \mathrm{O}\right]\left(\mathrm{SeO}_{3}\right)_{4}, \mathrm{MnBi}\left(\mathrm{SeO}_{3}\right)_{2} \mathrm{Cl}, \mathrm{Mn}^{\mathrm{II}} \mathrm{Mn}^{\mathrm{II}}\left(\mathrm{SeO}_{3}\right)_{2} \mathrm{Cl}$, $\mathrm{Mn}_{5}{ }_{5}\left(\mathrm{SeO}_{3}\right)_{2} \mathrm{Cl}_{6}$, and $\mathrm{Mn}_{4}\left(\mathrm{Mn}_{5}, \mathrm{Bi}\right)\left(\mathrm{SeO}_{3}\right)_{8} \mathrm{Cl}_{5}$, respectively.

\section{Results}

\section{Crystal structure of $\mathrm{Mn}_{2}\left[\mathrm{Bi}_{2} \mathrm{O}\right]\left(\mathrm{SeO}_{3}\right)_{4}(\mathrm{I})$}

In contrast to the other phases reported in this work, $\mathrm{Mn}_{2}\left[\mathrm{Bi}_{2} \mathrm{O}\right]\left(\mathrm{SeO}_{3}\right)_{4}$ (I) does not contain any halide anions. Its crystal structure contains one $\mathrm{Bi}$ site coordinated by eight oxygen atoms with the average $<\mathrm{Bi}-\mathrm{O}>$ distance equal to $2.481 \AA$. The coordination polyhedron of $\mathrm{Bi}^{\mathrm{III}}$ can

Tab. 1: Experimental parameters of the CVT reactions (transport agent: $\mathrm{Cl}^{-}$).

\begin{tabular}{|c|c|c|c|c|c|c|c|}
\hline $\begin{array}{l}\text { Heating } \\
\text { time }\end{array}$ & Temp. & $\begin{array}{l}\text { Dwell } \\
\text { time }\end{array}$ & $\begin{array}{l}\text { Target } \\
\text { temp. }\end{array}$ & $\begin{array}{l}\text { Cooling } \\
\text { time }\end{array}$ & $\begin{array}{l}\text { Cooling } \\
\text { rate }\end{array}$ & Main products & Additional products \\
\hline $2 \mathrm{~h}$ & $400^{\circ} \mathrm{C}$ & $24 \mathrm{~h}$ & $200^{\circ} \mathrm{C}$ & $100 \mathrm{~h}$ & $2.0^{\circ} \mathrm{C} / \mathrm{h}$ & $\mathrm{MnBi}\left(\mathrm{SeO}_{3}\right)_{2} \mathrm{Cl}(\mathrm{II})$ (brown plates) & $\mathrm{Bi}_{6}\left(\mathrm{SeO}_{3}\right)_{4} \mathrm{Cl}_{10}[7]$ (transparent plates) \\
\hline $2 \mathrm{~h}$ & $400^{\circ} \mathrm{C}$ & $24 \mathrm{~h}$ & $200^{\circ} \mathrm{C}$ & $72 \mathrm{~h}$ & $2.8^{\circ} \mathrm{C} / \mathrm{h}$ & $\mathrm{Mn}^{\prime \prime} \mathrm{Mn}^{\prime \prime \prime}\left(\mathrm{SeO}_{3}\right)_{2} \mathrm{Cl}$ (III) (brown prisms) & $\mathrm{Bi}_{6}\left(\mathrm{SeO}_{3}\right)_{4} \mathrm{Cl}_{10}[7]$ (transparent plates) \\
\hline $3 \mathrm{~h}$ & $450^{\circ} \mathrm{C}$ & $216 \mathrm{~h}$ & $200^{\circ} \mathrm{C}$ & $100 \mathrm{~h}$ & $2.5^{\circ} \mathrm{C} / \mathrm{h}$ & $\mathrm{Mn}_{5}\left(\mathrm{SeO}_{3}\right)_{2} \mathrm{Cl}_{6}(\mathrm{IV})$ (brown plates) & $\mathrm{Bi}_{6}\left(\mathrm{SeO}_{3}\right)_{4} \mathrm{Cl}_{10}[7]$ (transparent plates) \\
\hline $3 \mathrm{~h}$ & $450^{\circ} \mathrm{C}$ & $48 \mathrm{~h}$ & $200^{\circ} \mathrm{C}$ & $100 \mathrm{~h}$ & $2.5^{\circ} \mathrm{C} / \mathrm{h}$ & $\mathrm{Mn}_{4}\left(\mathrm{Mn}_{5}, \mathrm{Bi}\right)\left(\mathrm{SeO}_{3}\right)_{8} \mathrm{Cl}_{5}(\mathrm{~V})$ (brown prisms) & $\gamma-\mathrm{Bi}\left(\mathrm{SeO}_{3}\right) \mathrm{Cl}[38]$ (transparent plates) \\
\hline
\end{tabular}


Tab. 2: Crystallographic data and refinement parameters for $\mathrm{Mn}_{2}\left[\mathrm{Bi}_{2} \mathrm{O}\right]\left(\mathrm{SeO}_{3}\right)_{4}(\mathrm{I}), \mathrm{MnBi}\left(\mathrm{SeO}_{3}\right)_{2} \mathrm{Cl}(\mathrm{II}), \mathrm{Mn}^{\prime \prime} \mathrm{Mn}^{\prime \prime \prime}\left(\mathrm{SeO}_{3}\right)_{2} \mathrm{Cl}(\mathrm{III}), \mathrm{Mn}_{5}{ }_{5}\left(\mathrm{SeO}_{3}\right)_{2} \mathrm{Cl}$ (IV), and $\mathrm{Mn}_{4}\left(\mathrm{Mn}_{5}, \mathrm{Bi}\right)\left(\mathrm{SeO}_{3}\right)_{8} \mathrm{Cl}_{5}(\mathrm{~V})$.

\begin{tabular}{|c|c|c|c|c|c|}
\hline & I & II & III & IV & v \\
\hline$M_{\mathrm{r}}\left(\mathrm{g} \mathrm{mol}^{-1}\right)$ & 1051.68 & 553.29 & 399.25 & 370.66 & 1896.37 \\
\hline Space group & Pccn & $P \overline{1}$ & $P \overline{1}$ & $C 2 / c$ & $\mathrm{Pbcm}$ \\
\hline$a(\AA)$ & $10.8771(3)$ & $7.0926(8)$ & $6.1593(4)$ & $11.555(2)$ & $10.7914(2)$ \\
\hline$b(\AA)$ & $19.9770(5)$ & $7.2695(6)$ & $6.9939(6)$ & $6.1888(13)$ & $15.9782(3)$ \\
\hline$c(\AA)$ & $5.5058(1)$ & $8.0160(8)$ & $8.6204(7)$ & $20.273(4)$ & $17.5682(3)$ \\
\hline$\alpha\left(^{\circ}\right)$ & 90 & $88.226(4)$ & $105.489(6)$ & 90 & 90 \\
\hline$\beta\left(^{\circ}\right)$ & 90 & $72.005(3)$ & $105.559(6)$ & $96.298(4)$ & 90 \\
\hline$\gamma\left({ }^{\circ}\right)$ & 90 & $64.560(4)$ & $99.648(6)$ & 90 & 90 \\
\hline$V\left(\AA^{3}\right)$ & 1196.37(5) & $352.47(6)$ & $333.10(5)$ & $1441.0(5)$ & $3029.23(10)$ \\
\hline$Z$ & 4 & 2 & 2 & 8 & 4 \\
\hline$\rho\left(\mathrm{g} / \mathrm{cm}^{3}\right)$ & 5.839 & 5.213 & 3.981 & 3.417 & 4.158 \\
\hline$\mu\left(\mathrm{mm}^{-1}\right)$ & 43.63 & 37.40 & 15.09 & 10.43 & 19.55 \\
\hline$\lambda\left(\mathrm{MoK}_{\alpha}\right)(\AA)$ & 0.71073 & 0.71073 & 0.71073 & 0.71073 & 0.71073 \\
\hline Total rflns & 8112 & 7238 & 4095 & 8029 & 32242 \\
\hline Indep rflns & 1895 & 2194 & 2006 & 1860 & 4767 \\
\hline$R_{\mathrm{int}}$ & 0.0247 & 0.0198 & 0.0450 & 0.0545 & 0.0310 \\
\hline$R_{1}^{\operatorname{lnt}}[I>2 \sigma(I)]$ & 0.0285 & 0.0211 & 0.0498 & 0.0275 & 0.0220 \\
\hline$w R_{2}[I>2 \sigma(I)]$ & 0.0620 & 0.0443 & 0.1147 & 0.0468 & 0.0529 \\
\hline$R_{1}$ [all data] & 0.0325 & 0.0221 & 0.0775 & 0.0456 & 0.0317 \\
\hline$w R_{2}$ [all data] & 0.0637 & 0.0447 & 0.1264 & 0.0511 & 0.0565 \\
\hline GOF & 1.143 & 1.059 & 0.986 & 1.001 & 1.021 \\
\hline$\Delta \rho_{\max }, \Delta \rho_{\min }\left(e \AA^{-3}\right)$ & $2.54,-1.47$ & $1.89,-1.69$ & $2.56,-1.55$ & $0.58,-0.67$ & $0.73,-1.16$ \\
\hline${ }_{\mathrm{G}, \text { total }}$ (bits/u.cell) & 288.955 & 76.107 & 76.107 & 125.421 & 884.263 \\
\hline
\end{tabular}

aStructural complexity, see details in discussion part.

be described as a strongly distorted square antiprism. The interesting feature of the crystal structure of $I$ is the presence of an 'additional' oxygen atom (O7), which is coordinated solely by four $\mathrm{Bi}^{\mathrm{III}}$ cations forming oxocentered $\left(\mathrm{OBi}_{4}\right)^{10+}$ tetrahedra [26]. The $\mathrm{OBi}_{4}$ tetrahedra share trans-oriented edges to form infinite $\left[\mathrm{Bi}_{2} \mathrm{O}\right]^{4+}$ chains elongated along the $c$-axis (Figure 1b). The $07 \cdots 07$ distance is $2.753(3) \AA$. The $\mathrm{Bi} \cdot \mathrm{Bi}$ edge-lengths are of 3.751(5) $\AA$. Such chains are rather common in $\mathrm{Bi}(\mathrm{III})$ oxysalts, e.g. in $\left[\mathrm{Bi}_{2} \mathrm{O}\right]\left(\mathrm{AuO}_{4}\right)$ [42].
One crystallographically independent $\mathrm{Mn}^{\mathrm{II}}$ cation site has a distorted octahedral environment with the $\mathrm{Mn}-\mathrm{O}$ bond lengths in the range of 2.138-2.309 Å. A bond valence sum calculation gives a value of 1.93 v.u. (valence units) for this site, confirming an oxidation state of 2 for $\mathrm{Mn}$ cations. Each $\mathrm{MnO}_{6}$ octahedron shares two edges with adjacent octahedra thus forming $\left[\mathrm{MnO}_{4}\right]^{6-}$ zigzag chains running along the $c$-axis (Figure 1c). The $\mathrm{Mn} \cdots \mathrm{Mn}$ distance is 3.498(1) $\AA$. (a)

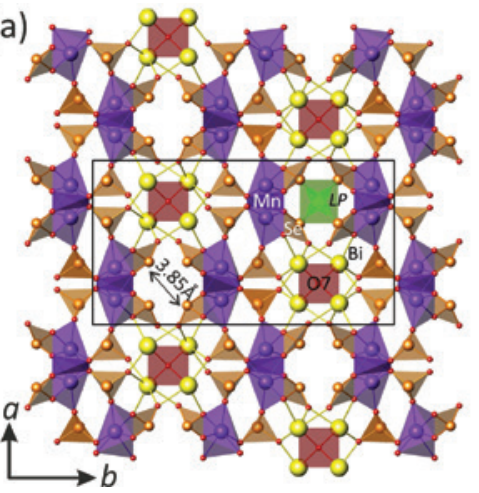

(b)

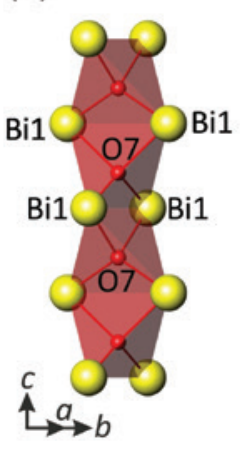

(c)

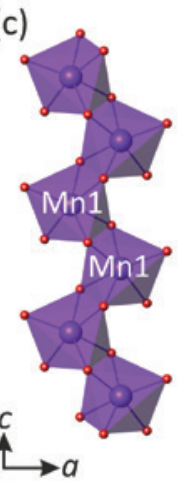

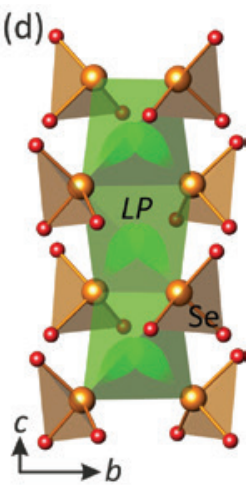

Fig. 1: Projection of the crystal structure of $\mathrm{Mn}_{2}\left[\mathrm{Bi}_{2} \mathrm{O}\right]\left(\mathrm{SeO}_{3}\right)_{4}$ (I) (a) built up from $\left[\mathrm{Bi}_{2} \mathrm{O}\right]^{4+}$ (b) and $\left[\mathrm{MnO}_{4}\right]^{6-}$ chains (c); pseudo-tetrahedral channels filled by lone electron pairs (LP, green) of Se cations (d). 
Two crystallographically independent $\mathrm{Se}^{\mathrm{IV}}$ sites adopt a typical triangular pyramidal coordination with Se atoms located at the apices, in agreement with the stereochemical activity of lone electron pairs. The average $<$ Se-O > bond lengths are 1.702 and $1.700 \AA$ for Se1 and Se2, respectively.

In the 3D framework of $\mathbf{I}$, the $\left[\mathrm{Bi}_{2} \mathrm{O}\right]^{4+}$ chains are linked through $\mathrm{SeO}_{3}$ groups and $\left[\mathrm{MnO}_{4}\right]^{6-}$ chains resulting in a formation of pseudo-tetrahedral [Se] $]^{\mathrm{IV}}$ empty channels along the $c$-axis occupied by lone electron pairs of $\mathrm{Se}^{\mathrm{IV}}$ cations as demonstrated in Figure 1d.

\section{Crystal structure of $\mathrm{MnBi}\left(\mathrm{SeO}_{3}\right)_{2} \mathrm{Cl}$ (II)}

In the crystal structure of $\mathrm{MnBi}\left(\mathrm{SeO}_{3}\right)_{2} \mathrm{Cl}$ (II), there is one symmetrically unique $\mathrm{Mn}$ site occupied by $\mathrm{Mn}^{\mathrm{II}}$ cations. $\mathrm{Mn}^{\mathrm{II}}$ have mixed-ligand coordination environments (calculated BVS equals 1.84 v.u.), thus, forming $\left(\mathrm{MnO}_{4} \mathrm{Cl}_{2}\right)^{8-}$ octahedra $(<\mathrm{Mn}-\mathrm{O}\rangle=2.242 \AA)$, which are interconnected via common $\mathrm{Cl} \cdots \mathrm{Cl}$ and $\mathrm{O} \cdots \mathrm{O}$ edges producing infinite zigzag chains running along the $a$-axis with the Mn $\cdots \mathrm{Mn}$ distance of 3.705(1) Å. The chains are further linked by selenite groups into sheets parallel to (001) (Figure 2a). One symmetrically unique $\mathrm{Bi}^{\text {III }}$ cation has a distorted nine-fold coordination by eight oxygen atoms $(<\mathrm{Bi}-\mathrm{O}\rangle=2.534 \AA)$ and one chlorine atom $(\mathrm{Bi}-\mathrm{Cl}=2.936(1) \AA)$. The $\mathrm{Bi}^{\mathrm{III}}$ cations provide linkage between the sheets and compensate for their negative charge (Figure $2 \mathrm{~b}$ ).

During the structure solution and refinement, two possible orientations of the Se2-based selenite anion were observed due to the disorder of three $\mathrm{O}$ sites, which may lead to a local twist of the $\mathrm{SeO}_{3}$ ion (Figure 2c). The refinement of the occupancies gave the ratio of $0.67 / 0.33$ for each pair of the disordered $\mathrm{O}$ sites. Thus, we consider two possible sets of the Se2 environment by the 0 atoms: 05A, 04A,

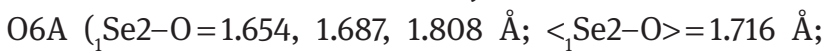
weight $=67 \%)$ and O6B, O4B, O5B ( ${ }_{2} \mathrm{Se} 2-\mathrm{O}=1.472,1.730$, $1.795 \AA$. $<_{2} \mathrm{Se} 2-0>=1.666 \AA$; weight $=33 \%$ ). The average $<$ Se1-O $>$ bond length and the occupancy-weighted $<$ Se2$\mathrm{O}>$ bond length are 1.702 and $1.700 \AA$, respectively.

\section{Crystal structure of $\mathrm{Mn}^{\prime \prime} \mathrm{Mn}^{\prime \prime \prime}\left(\mathrm{SeO}_{3}\right)_{2} \mathrm{Cl}$ (III)}

Chemically, the compound III corresponds to the substitution of $\mathrm{Bi}^{\mathrm{III}}$ for $\mathrm{Mn}^{\text {II }}$ in the formula of the phase II. Unsurprisingly, the different anionic affinities of the two cations lead to very different topologies. The crystal structure of $\mathrm{Mn}^{\mathrm{II}} \mathrm{Mn}^{\mathrm{III}}\left(\mathrm{SeO}_{3}\right)_{2} \mathrm{Cl}$ (III) is based upon 2D electroneutral sheets separated by lone electron pairs of selenite
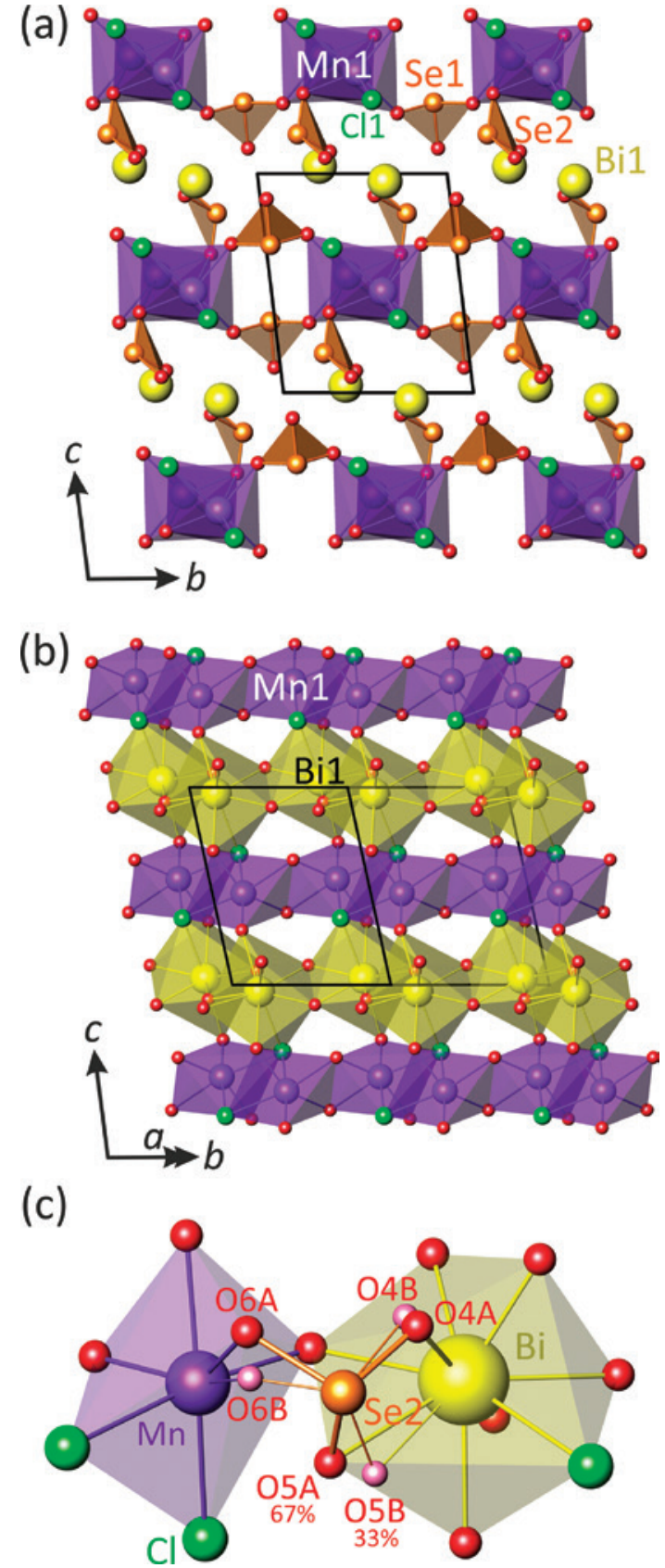

Fig. 2: General projections of the crystal structure of $\mathrm{MnBi}\left(\mathrm{SeO}_{3}\right)_{2} \mathrm{Cl}$ (II) along [010] - (a) and [110] - (b) (disordered 0 sites and selenite groups in $b$ are omitted for clarity); anionic arrangement of cations in the structure - (c).

groups and interacting with each other due to weak secondary interactions only (Figure 3a). In the structure of III, there are two crystallographically independent Mn sites occupied by $\mathrm{Mn}^{\mathrm{II}}$ and $\mathrm{Mn}^{\mathrm{III}}$ cations. Both sites have irregular octahedral environments formed by five $\mathrm{O}$ and one $\mathrm{Cl}$ for $\mathrm{Mn} 1$ and six $\mathrm{O}$ for $\mathrm{Mn} 2$, with the average $\mathrm{Mn}-\mathrm{O}$ bond lengths of 2.084 and $2.226 \AA$ for the Mn1 and Mn2 sites, 


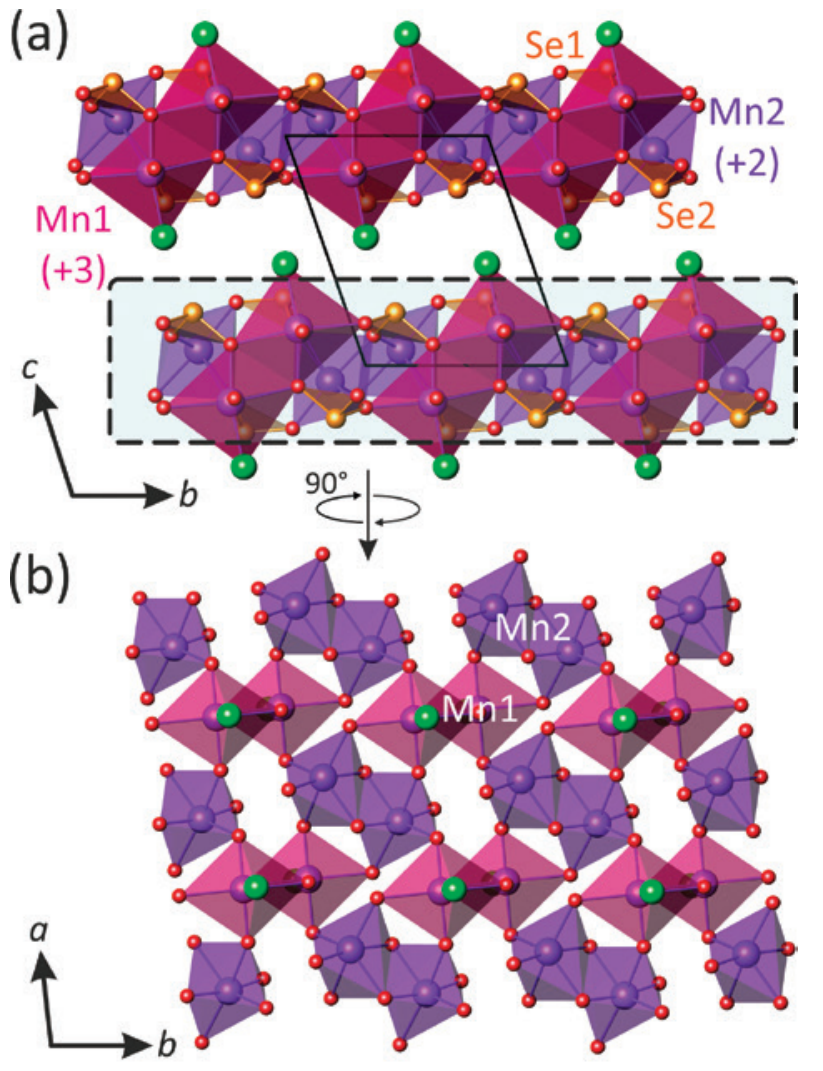

(c)

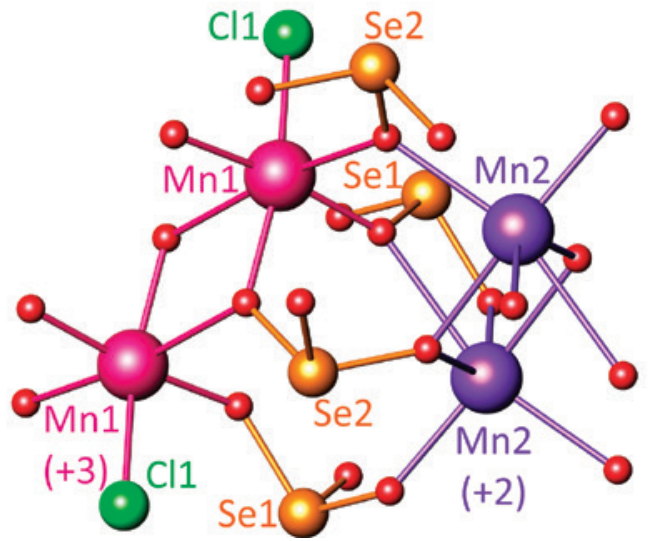

Fig. 3: General projection of the crystal structure of $\mathrm{Mn}^{\prime \prime} \mathrm{Mn}^{\text {"I' }}\left(\mathrm{SeO}_{3}\right)_{2} \mathrm{Cl}$ (III) along [010] - (a) and its sheet - (b) (selenite groups are omitted for clarity); anionic arrangement of metal cations in the structure $-(c)$.

respectively. The calculated bond valence sums give 3.15 and 2.03 v.u. for Mn1 and Mn2, respectively, in good agreement with the $\mathrm{Mn} 1^{\mathrm{III}}$ and $\mathrm{Mn} 2^{\mathrm{II}}$ charge ordering. An overview of coordination geometry of mixed-ligand $\mathrm{MnO}_{n} \mathrm{Cl}_{m}$ coordination polyhedra observed in Mn-containing inorganic compounds is discussed below in details. It is noteworthy that this mixed valence compounds result from CVT experiments, while divalent $\mathrm{Mn}^{\mathrm{II}}$ species are stable in our hydrothermal conditions. The structure of III contains two independent $\mathrm{Se}^{\mathrm{IV}}$ cations in their typical $\left(\mathrm{SeO}_{3}\right)^{2-}$ triangular pyramids. The average $<\mathrm{Se}-\mathrm{O}>$ distance is 1.702 and $1.708 \AA$ A for the Se1 and Se2, respectively.

The electroneutral sheets of III are formed by $\left(\mathrm{Mn}_{2}{ }_{2} \mathrm{O}_{10}\right)^{16-}$ and $\left(\mathrm{Mn}_{2}{ }_{2} \mathrm{O}_{8} \mathrm{Cl}_{2}\right)^{12-}$ dimers sharing oxygenbased edges (Figure $3 \mathrm{~b}$ ). Dimers are connected to each other in 2D slabs by oxygen corner sharing. Additional linkage between the Mn-centered octahedra is provided by the $\mathrm{SeO}_{3}$ groups (Figure 3c) with the lone pairs of electrons oriented toward the interstitial space between the plane of the sheet.

\section{Crystal structure of $\mathrm{Mn}_{5}\left(\mathrm{SeO}_{3}\right)_{2} \mathrm{Cl}_{6}$ (IV)}

In the structure of $\mathrm{Mn}_{5}\left(\mathrm{SeO}_{3}\right)_{2} \mathrm{Cl}_{6}(\mathrm{IV})$, there are three crystallographically inequivalent octahedrally coordinated $\mathrm{Mn}$ sites. The Mn1 and Mn3 sites are surrounded by two oxygen and four chlorine anions each with the average $\langle\mathrm{Mn}-\mathrm{O}\rangle$ bond lengths of 2.073 and $2.157 \AA$ for Mn1 and Mn3, respectively. The average $<\mathrm{Mn}-\mathrm{Cl}>$ distance is $2.594 \AA$ for both sites. The Mn2 site forms a strongly distorted octahedron by $4 \mathrm{O}^{2-}$ and $2 \mathrm{Cl}^{-}$with the average $\left.<\mathrm{Mn}-\mathrm{O}\right\rangle$ and $\langle\mathrm{Mn}-\mathrm{Cl}\rangle$ lengths of 2.226 and $2.552 \AA$, respectively. The BVS analysis for the Mn sites indicates 2.09, 1.88, and 1.91 v.u. (valence units) for Mn1, Mn2 and Mn3, which is well consistent with $\mathrm{Mn}^{\mathrm{II}}$ species. The structure of IV also contains one inequivalent Se site adopting a typical triangular pyramidal coordination with stereochemicaly active lone pair of electrons. The average $<\mathrm{Se}-\mathrm{O}>$ bond length is $1.704 \AA$. Note that the $\mathrm{SeO}_{3}$ groups are 'chelating' sharing a common $\mathrm{O} \cdots \mathrm{O}$ edge

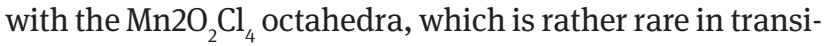
tional-metal selenites (Figure 4). Similar 'chelating' feature

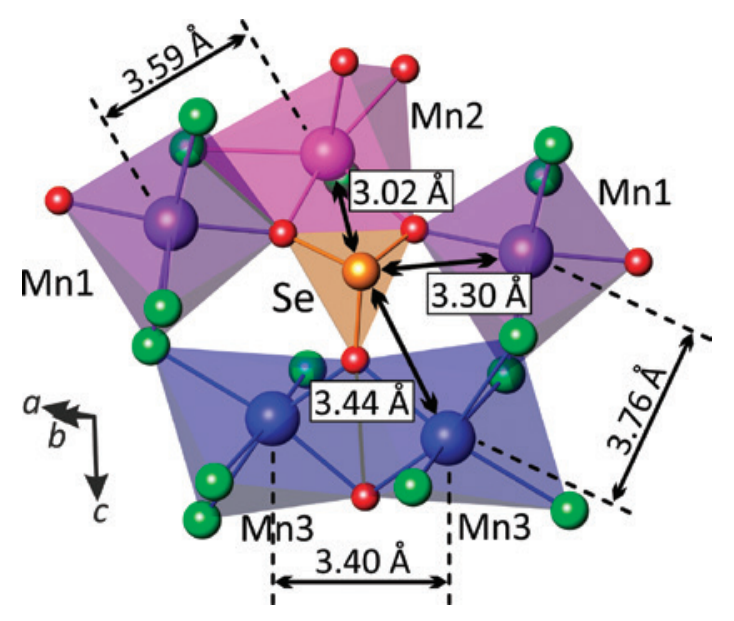

Fig. 4: Fragment of $\mathrm{Mn}_{5}\left(\mathrm{SeO}_{3}\right)_{2} \mathrm{Cl}_{6}$ (IV) showing the cationic arrangement. The shortest interatomic distances are given. 
(a)

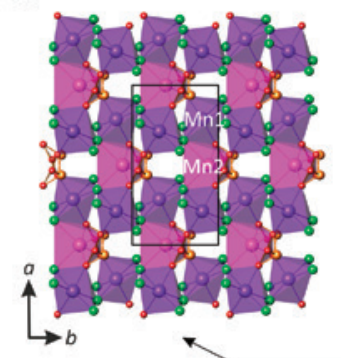

(b)

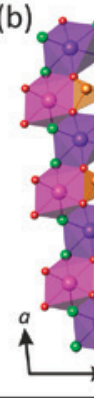

(c)

Fig. 5: General projection of the crystal structure of $\mathrm{Mn}_{5}\left(\mathrm{SeO}_{3}\right)_{2} \mathrm{Cl}_{6}(\mathrm{IV})$ along [010] - (b) and two Mn-based 2D-blocks (a) and (c).

exists in the structure of $\mathrm{LiFePO}_{4}$, where strong $\mathrm{P}-\mathrm{O}$ bonds of $\mathrm{PO}_{4}$ anions edge-shared with $\mathrm{FeO}_{6}$ octahedra induce the strong polarization of oxygen ions toward $\mathrm{P}$, which lowers the covalency of the $\mathrm{Fe}-\mathrm{O}$ bonds, thus increasing the potential due to a strong inductive effect acting on two $\mathrm{O}$ atoms [43].

In the structure of IV, each $\mathrm{Mn} 1 \mathrm{O}_{2} \mathrm{Cl}_{4}$ and $\mathrm{Mn}_{2} \mathrm{O}_{4} \mathrm{Cl}_{2}$ octahedron shares one common $\mathrm{O} \cdots \mathrm{Cl}$ edge with an adjacent octahedron. The $\mathrm{Mn1O}_{2} \mathrm{Cl}_{4}$ octahedron is also connected to the $\mathrm{Cl}$-vertex of this edge to form a complex

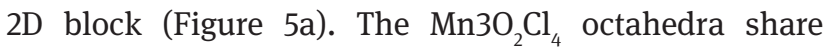
common $\mathrm{O} \cdots \mathrm{O}$ and $\mathrm{Cl} \cdots \mathrm{Cl}$ edges with each other to polymerize into a honeycomb-like sheet (Figure 5c). The sheets are linked via common $\mathrm{Cl}^{-}$and $\mathrm{O}^{2-}$ ions with the $\mathrm{Mn1O}_{2} \mathrm{Cl}_{4}$ and $\mathrm{SeO}_{3}$ polyhedra, respectively, and are regularly sandwiched between the $2 \mathrm{D}$ blocks, thus forming a complex 3D framework as shown in Figure 5b. Note that the $2 \mathrm{D}$ blocks are polar as can be seen from the fact that the lone electron pairs of $\mathrm{Se}^{\mathrm{IV}}$ cations are oriented towards the same direction in the blocks. The shortest interatomic $\mathrm{Mn} \cdots \mathrm{Mn}$ and $\mathrm{Mn} \cdots$ Se distances in the structure of IV are given in Figure 4. Relatively short distances (Se $\cdots \mathrm{Mn} 2=3.02 \AA$; Mn3 $\cdots \mathrm{Mn} 3=3.44 \AA$ $)$ suggest interesting frustrated magnetism considering both the superexchange $\mathrm{Mn}-\mathrm{O}-\mathrm{Mn}$ interactions against the super-super

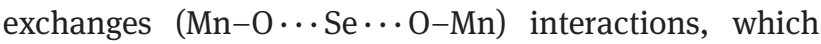
may dominate over the former interactions $[25,44]$.

\section{Crystal structure of $\mathrm{Mn}_{4}\left(\mathrm{Mn}_{5}, \mathrm{Bi}\right)\left(\mathrm{SeO}_{3}\right)_{8} \mathrm{Cl}_{5}(\mathrm{~V})$}

The compound $\mathrm{Mn}_{4}\left(\mathrm{Mn}_{5}, \mathrm{Bi}\right)\left(\mathrm{SeO}_{3}\right)_{8} \mathrm{Cl}_{5}(\mathbf{V})$ demonstrates a partially $\mathrm{Bi} / \mathrm{Mn}$ disordered structure. Its crystal structure can be described as based upon 2D blocks composed of distorted square antiprisms of four crystallographically inequivalent mixed sites statistically occupied by $\mathrm{Mn}^{\mathrm{II}}$ and $\mathrm{Bi}^{\mathrm{III}}$ cations. The edge-sharing antiprisms are arranged in a staggered manner (Figure 6a). A refinement of the mixed sites gave the following cationic distributions: $0.97 \mathrm{Mn}^{\mathrm{II}} / 0.03 \mathrm{Bi}^{\mathrm{III}}, \quad 0.92 \mathrm{Mn}^{\mathrm{II}} / 0.08 \mathrm{Bi}^{\mathrm{III}}, \quad 0.87 \mathrm{Mn}^{\mathrm{II}} / 0.13 \mathrm{Bi}^{\mathrm{III}}$, and $0.37 \mathrm{Mn}^{\mathrm{II}} / 0.63 \mathrm{Bi}^{\mathrm{III}}$ for $\mathrm{Mn} 3, \mathrm{Mn} 4, \mathrm{Mn} 5$, and Bi6, respectively, under the restraints of a total neutral charge. (a)

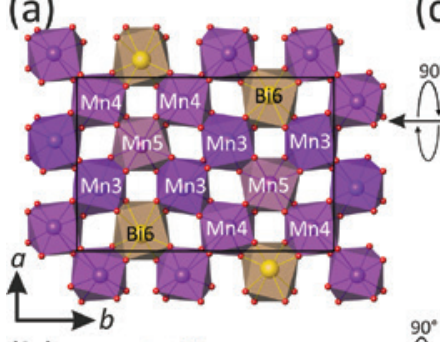

(b)

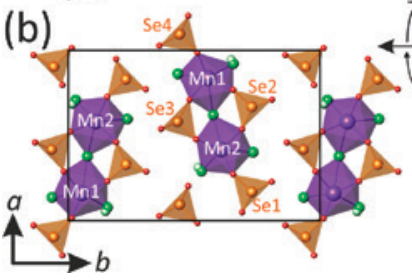

(c)

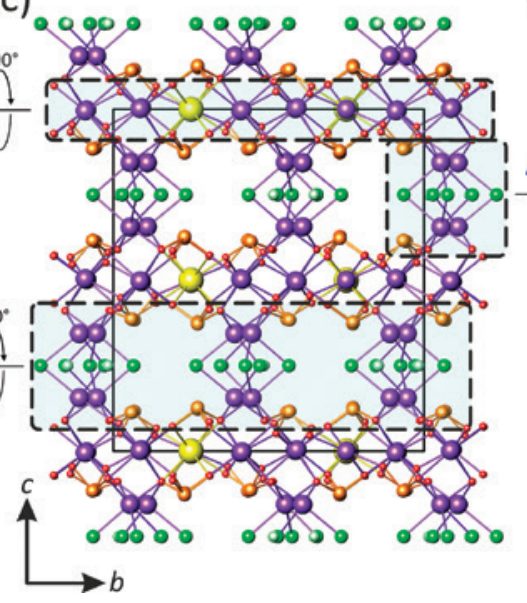

(d)

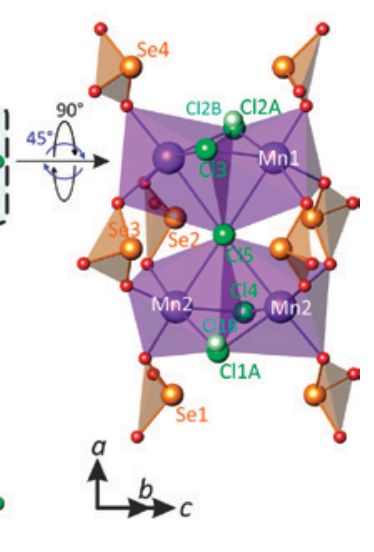

Fig. 6: Projection of the crystal structure of $\mathrm{Mn}_{4}\left(\mathrm{Mn}_{5}, \mathrm{Bi}\right)\left(\mathrm{SeO}_{3}\right)_{8} \mathrm{Cl}_{5}(\mathrm{~V})$ along [100] - (c), the sheets of square antiprisms - (a), the tetrameric unit - (d), and their arrangement in the structure - (b). 
In the structure of $\mathbf{V}$, there are also two fully ordered $\mathrm{Mn}^{\mathrm{II}}$ sites (Mn1 and Mn2), which are octahedrally coordinated by three oxygen $(<\mathrm{Mn} 1-\mathrm{O}>=2.143 \AA$, $<\mathrm{Mn} 2-$ $\mathrm{O}>=2.130 \AA)$ and three chlorine $(<\mathrm{Mn} 1-\mathrm{Cl}>=2.640 \AA$, $<\mathrm{Mn} 2-\mathrm{Cl}>=2.623 \AA$ ) atoms each. Two octahedra share their common $\mathrm{Cl}_{3}$ face to form a dimer, which is further linked through one of its $\mathrm{Cl}$ corners with an adjacent dimer into a square-like tetrameric unit. Four symmetrically inequivalent $\mathrm{Se}^{\mathrm{IV}}$ triangular pyramids $(<\mathrm{Se}-\mathrm{O}>=1.702,1.702,1.697$, and $1.692 \AA$ for Se1, Se2, Se3, and Se4) are connected to the $\mathrm{O}$ corners of the tetrameric unit as shown in Figure 6d. The inspection of Fourier difference electron-density maps showed that two of the five crystallographically independent $\mathrm{Cl}^{-}$sites are disordered. The refinement of their occupancies indicated identical 0.58/0.42 ratios for both Cl1A/ $\mathrm{Cl} 1 \mathrm{~B}$ and $\mathrm{Cl} 2 \mathrm{~A} / \mathrm{Cl} 2 \mathrm{~B}$ sites. The arrangement of the tetrameric units in the structure of $\mathbf{V}$ is shown in Figure $6 \mathrm{~b}$. This $\mathrm{Cl}$ disorder reflects the influence of the local $\mathrm{Mn}^{\mathrm{II}} / \mathrm{Bi}^{\mathrm{III}}$ occurrence in the layers with locally different oxygen coordination. As can be seen from Table 3, the disordering of the two aliovalent metal sites is in good agreement with our BVS calculations and differences of ionic radii $\left(r_{\mathrm{Bi}}^{\text {III }}{ }_{\text {(octa) }}=1.03 \AA\right.$, $r_{\mathrm{Mn} \text { (HS, octa) }}^{\text {II }}=0.83 \AA ̊$ ). Such significant differences suggest local configurations depending on the involved cations while the average structure is refined. Therefore, for all mixed sites $\mathrm{Bi}^{\mathrm{III}}$ seem over-bonded (BVS in range of 3.40-3.80 v.u. for

Tab. 3: Calculated BVS of cations in $\mathrm{Mn}_{4}\left(\mathrm{Mn}_{5}, \mathrm{Bi}\right)\left(\mathrm{SeO}_{3}\right)_{8} \mathrm{Cl}_{5}(\mathrm{~V})$.

\begin{tabular}{lrlr}
\hline Atom (occ.) & BVS (v.u.) & Atom (occ.) & BVS (v.u.) \\
\hline Mn1 & 2.03 & Bi5 $(0.135)$ & 3.78 \\
Mn2 & 2.04 & Bi6 $(0.630)$ & 3.40 \\
Mn3 (0.965) & 1.81 & Mn6 $(0.370)$ & 1.58 \\
Bi3 (0.035) & 3.80 & Se1 & 4.04 \\
Mn4 (0.917) & 1.84 & Se2 & 4.03 \\
Bi4 (0.083) & 3.83 & Se3 & 4.08 \\
Mn5 (0.865) & 1.78 & Se4 & 4.14 \\
\hline
\end{tabular}

the $\mathrm{Bi3}-\mathrm{Bi} 6$ sites), while $\mathrm{Mn}^{\mathrm{II}}$ appear under-bonded (BVS in range of 1.58-1.84 v.u. for the Mn3-Mn6 sites). The deviations from the ideal values is consistent with the refined $\mathrm{Mn} / \mathrm{Bi}$ ratio for each of these sites.

The tetrameric units are connected to the 2D sheets via sharing common $0 \cdots 0$ edges of octahedra or selenite pyramids with the square antiprisms resulting in a complex 3D framework with large pseudo-tetragonal empty channels occupied by lone electron pairs of $\mathrm{Se}^{\mathrm{IV}}$ cations along the $a$-axis (Figure 6c).

\section{Discussion}

The structural edifices of the new compounds reveal a remarkable variety of their different structure types. Four of them (I, III-V) are new and have never been observed in reported inorganic compounds to the best of our knowledge. Nevertheless, some relations to the crystal structures of already reported phases can be evaluated.

The structural motif of $\mathrm{Mn}_{2}\left[\mathrm{Bi}_{2} \mathrm{O}\right]\left(\mathrm{SeO}_{3}\right)_{4}$ (I) is closely related to the one observed in the structure of $\mathrm{Cu}\left[\mathrm{Bi}_{2} \mathrm{O}\right]$ $\left(\mathrm{SeO}_{3}\right)_{3}\left(\mathrm{H}_{2} \mathrm{O}\right)$ [45], which is also a transitional-metal selenite with $\left[\mathrm{Bi}_{2} \mathrm{O}\right]$ chains of trans-edge-sharing $\mathrm{OBi}_{4}$ tetrahedra. Here the $\left[\mathrm{Bi}_{2} \mathrm{O}\right]^{4+}$ chains are linked through $\left(\mathrm{CuO}_{5}\right)^{8-}$ square pyramids and $\left(\mathrm{SeO}_{3}\right)^{2-}$ triangular pyramids to form a 3D framework with channels occupied by the lone electron pairs on the $\mathrm{Se}^{\mathrm{IV}}$ cations (Figure 7a). Interestingly, the condensation of the $\left[\mathrm{M}_{2} \mathrm{O}\right]^{m+}$ single chains through the equatorial edges of $\left(\mathrm{OM}_{4}\right)$ tetrahedra produces the family of chains with the general formula $\left[M_{n+1} \mathrm{O}_{n}\right]^{m+}$, where $n$ is the chain multiplicity [26]. For example, in the crystal structures of $\left[\mathrm{Tb}_{2} \mathrm{O}\right]\left(\mathrm{SeO}_{3}\right)_{2}[46]$ and $\left[\mathrm{M}_{3} \mathrm{O}_{2}\right]\left(\mathrm{SeO}_{3}\right)_{2} \mathrm{Cl}$ $\left(M^{\mathrm{III}}=\mathrm{Tb}\right.$ [47] and Y [48]) with $n$ equaled 1 and 2, respectively, the single $\left[\mathrm{Tb}_{2} \mathrm{O}\right]^{4+}$ and double $\left[\mathrm{M}_{3} \mathrm{O}_{2}\right]^{5+}$ chains of oxocentered tetrahedra are linked via selenite anions into similar 3D frameworks (Figure 7b,c). (a)

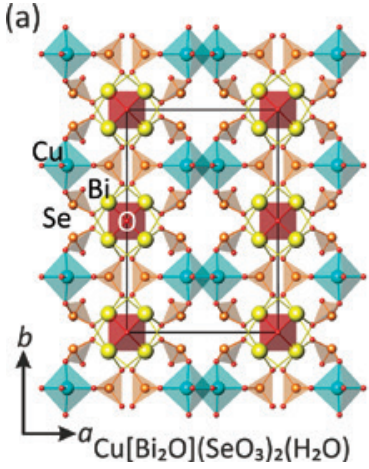

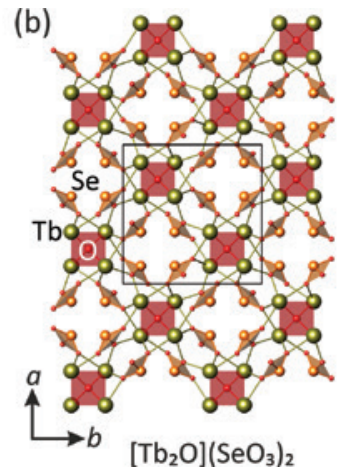

Fig. 7: Projections of the crystal structures of $\mathrm{Cu}\left[\mathrm{Bi}_{2} \mathrm{O}\right]\left(\mathrm{SeO}_{3}\right)_{2}\left(\mathrm{H}_{2} \mathrm{O}\right)[45](\mathrm{a}),\left[\mathrm{Tb}_{2} \mathrm{O}\right]\left(\mathrm{SeO}_{3}\right)_{2}[46]$ (b) and $\left[\mathrm{Tb}_{3} \mathrm{O}_{2}\right]\left(\mathrm{SeO}_{3}\right)_{2} \mathrm{Cl}[47](\mathrm{c})$. 
Despite the similarity in their chemical formulae, the crystal structures of $\mathrm{MnBi}\left(\mathrm{SeO}_{3}\right)_{2} \mathrm{Cl}$ (II) and $\mathrm{Mn}^{\mathrm{II}} \mathrm{Mn}^{\mathrm{III}}\left(\mathrm{SeO}_{3}\right)_{2} \mathrm{Cl}$ (III) belong to different structure types. The structure of $\mathrm{MnBi}\left(\mathrm{SeO}_{3}\right)_{2} \mathrm{Cl}$ (II) is isotypic with the previously reported $\mathrm{MnSm}\left(\mathrm{SeO}_{3}\right)_{2} \mathrm{Cl}, \mathrm{CoSm}\left(\mathrm{SeO}_{3}\right)_{2} \mathrm{Cl}$, and $\mathrm{CuGd}\left(\mathrm{SeO}_{3}\right)_{2} \mathrm{Cl}$ [49], whereas the structure type of III is reported here for the first time. It is of interest, however, that, in the $\mathrm{Mn}_{5}\left(\mathrm{TeO}_{3}\right)_{4} \mathrm{Cl}_{2}$ [50] and $\mathrm{Mn}_{4}\left(\mathrm{TeO}_{3}\right)\left(\mathrm{SiO}_{4}\right) X_{2}$ $(X=\mathrm{Cl}, \mathrm{Be})[51]$ compounds, chloride ions and lone electron pairs of $\mathrm{Te}^{\mathrm{IV}}$ protrude from the sheets in a similar way as observed in the structure of III, which means that the sheets are interconnected by the weak interactions only.

One of the interesting features of the crystal structure of $\mathrm{Mn}_{5}\left(\mathrm{SeO}_{3}\right)_{2} \mathrm{Cl}_{6}$ (IV) is the presence of honeycomb sheets composed of edge-sharing $\left(\mathrm{MnO}_{2} \mathrm{Cl}_{4}\right)$ octahedra (similar $\mathrm{Mn}^{\mathrm{II}}$ coordination has previously been reported in $\mathrm{Mn}_{9} \mathrm{Sb}_{8} \mathrm{O}_{16} \mathrm{Cl}_{10}$ [50]). The honeycomb sheets based on triangular lattices are of interest in terms of enhanced electron transport and 2D-magnetic frustration owing to significant $M \cdots M$ interactions [52]. For example, the structures of $\mathrm{Bi}_{3} \mathrm{Mn}_{4} \mathrm{O}_{12}\left(\mathrm{NO}_{3}\right)$ and $\mathrm{BiMnTeO}_{6}$ based upon honeycomb sheets of $\mathrm{Mn}^{\mathrm{IV}}$ and $\mathrm{Mn}^{\mathrm{III}}$ cations, respectively, are good model compounds of honeycomb antiferromagnets $[53,54]$. From this point of view, the further magnetic studies of the IV phase would be of interest, and efforts are now provided to prepare the single-phase material.

Regarding the unusual structure of $\mathrm{Mn}_{4}\left(\mathrm{Mn}_{5}, \mathrm{Bi}\right)$ $\left(\mathrm{SeO}_{3}\right)_{8} \mathrm{Cl}_{5}$ (V), its remarkable structural complexity (Figure 6) comes to our attention first. A quantitative evaluation of the structural complexity of the structure $\mathbf{V}$ can be done using the amount of Shannon information measured in bits per atom ( $I_{\mathrm{G}}$ in bits/atom) and per unit cell ( $I_{G, \text { total }}$ in bits/cell), according to Krivovichev approach [55-57]. The calculations using the ToposPro [58] software gave the structural information amounts, $I_{\mathrm{G}}$ and $I_{\mathrm{G}, \text { total }}$, 4.704 bits/atom and 884.263 bits/cell for the $\mathbf{V}$ compound, which allows classification of its structure as complex (only $0.03 \%$ of all reported inorganic compounds) [59]. The estimated structural complexity values for $\mathbf{I}-\mathbf{V}$ compounds are given in Table 2.

Note that the compound $\mathbf{V}$ bears a structural analogy to the $\mathrm{Na}_{2} \mathrm{Ln}_{3}\left(\mathrm{TeO}_{3}\right)_{4} X_{3}$ phases [60]. In their structures, there are layered blocks of distorted square $\mathrm{LnO}_{8}$ antiprisms arranged in check-wise fashion very similar to the blocks of $\mathrm{Mn} / \mathrm{BiO}_{8}$ antiprisms found in $\mathrm{Mn}_{4}\left(\mathrm{Mn}_{5}, \mathrm{Bi}\right)$ $\left(\mathrm{SeO}_{3}\right)_{8} \mathrm{Cl}_{5}$ (Figure $7 \mathrm{a}$ ). The phase $\mathbf{V}$ is the only one selenite with such structural motif, and it is a unique example of $\mathrm{Mn}^{\mathrm{II}}$ occupying sites more typical for $L n^{\mathrm{III}}$, to the best of our knowledge. It may be the $\mathrm{Se}^{\mathrm{IV}} / \mathrm{Mn}^{\mathrm{II}}$ and $\mathrm{Te}^{\mathrm{IV}} / L n^{\mathrm{III}}$ ratio which would favor such arrangement.

It is worth paying special attention also to four $8 e$ sites in the structure of $\mathbf{V}$, which are statistically occupied by $\mathrm{Mn}^{\mathrm{II}}$ and $\mathrm{Bi}^{\mathrm{III}}$ atoms. This relatively rare aliovalent substitution of $\mathrm{Mn}^{\mathrm{II}}$-based polyanionic compounds for $\mathrm{Bi}^{\mathrm{III}}$ has been previously found in $\mathrm{Bi} \sim{ }_{1.2} \mathrm{Mn}_{1.2} \mathrm{PO}_{5.5}$ [61]. Note also that despite the larger ionic radius of 6-coordinated $\mathrm{Mn}^{\mathrm{II}}$ (0.9 $\AA$ ) compared to $\mathrm{Mn}^{\mathrm{III}}(0.685 \AA)$, isovalent doping of $\mathrm{Bi}^{\mathrm{III}}$ (1.17 $\AA$ ) by $\mathrm{Mn}^{\mathrm{III}}$ has been reported so far in the sillenitetype $\mathrm{Bi}_{12}\left(\mathrm{Bi}_{0.53} \mathrm{Mn}_{0.47}\right) \mathrm{O}_{20}$ phase [62]. Meanwhile, the diversity of other aliovalent $M^{\mathrm{II}}(\mathrm{Cd}, \mathrm{Cu}, \mathrm{Zn}, \mathrm{Mg}, \mathrm{Co})$ cations incorporating mainly into oxocentered $\mathrm{O}(\mathrm{Bi}, M)_{4}$ tetrahedra is also known [63-67].

One of the interesting structural features of all the new phases is the presence of mixed-ligand $\mathrm{MnO}_{n} \mathrm{Cl}_{m}$ coordination polyhedra. Figure 8 summarizes all encountered
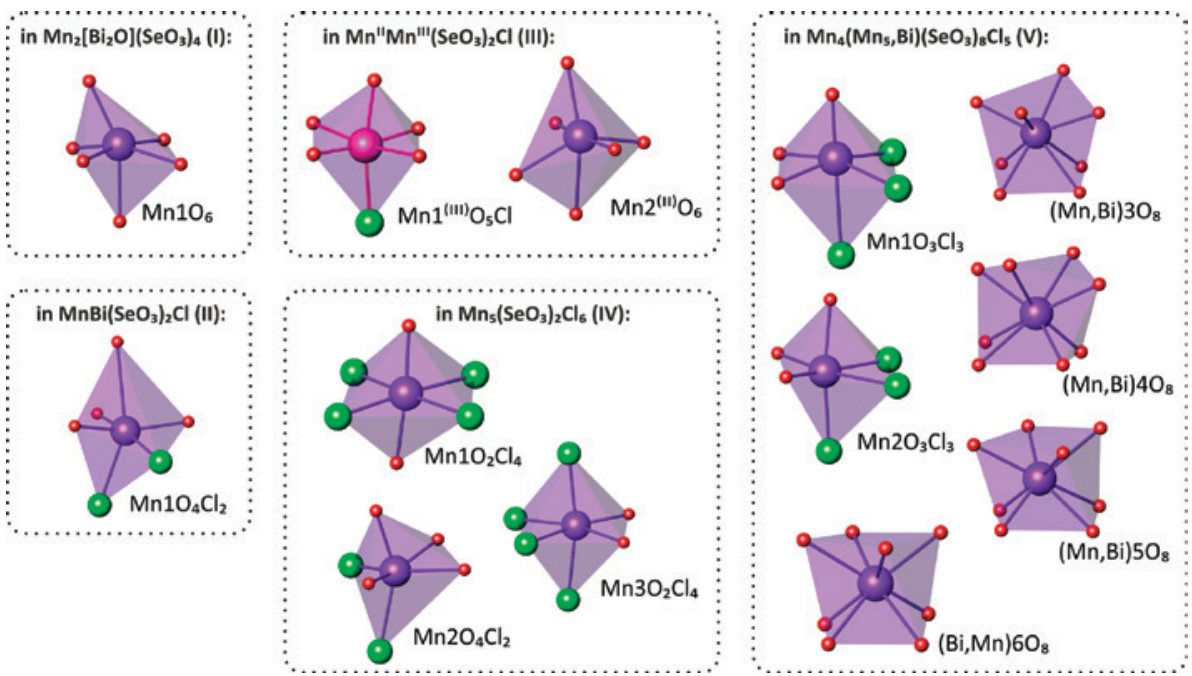

Fig. 8: Coordination polyhedra of the $\mathrm{Mn}^{1 / / I I I}$-filled sites in the structures of I-V. 
Tab. 4: Geometrical characteristics of mixed-ligand $\mathrm{MnO}_{n} \mathrm{Cl}_{m}$ coordination polyhedra in inorganic compounds.

\begin{tabular}{|c|c|c|c|c|c|c|c|}
\hline \multirow{2}{*}{$\begin{array}{l}\text { Coordination } \\
\text { number }\end{array}$} & \multirow[t]{2}{*}{ Geometry } & \multicolumn{3}{|c|}{ Average bond lengths and distortion } & \multirow[t]{2}{*}{ Site } & \multirow[t]{2}{*}{ Formula } & \multirow[t]{2}{*}{ Ref } \\
\hline & & $<M n-0>(\AA)$ & $<\mathrm{Mn}-\mathrm{Cl}>(\AA)$ & $\Delta_{d}, 10^{4}$ & & & \\
\hline \multicolumn{8}{|c|}{ Oxidation state of $\mathrm{Mn}:+3$} \\
\hline $6=[50-1 \mathrm{Cl}]$ & {$[(40)+(0+C l)]$} & 2.084 & 2.242 & 87 & $\mathrm{Mn} 1$ & $\mathrm{Mn}^{\prime \prime} \mathrm{Mn}^{\prime \prime \prime}\left(\mathrm{SeO}_{3}\right)_{2} \mathrm{Cl}$ & \\
\hline \multirow[t]{4}{*}{$6=[40-2 \mathrm{Cl}]$} & {$[(40)+(2 \mathrm{Cl})]$} & 1.895 & 2.702 & 323 & Mn1 & $\mathrm{Ba}_{2} \mathrm{Mn}\left(\mathrm{Si}_{2} \mathrm{O}_{7}\right) \mathrm{Cl}$ & [68] \\
\hline & & 1.891 & 2.905 & 461 & Mn1 & $\mathrm{FeMn}_{7} \mathrm{O}_{10} \mathrm{Cl}_{3}$ & [69] \\
\hline & & 1.890 & 2.831 & 406 & Mn1 & $\mathrm{Mn}_{8} \mathrm{O}_{10} \mathrm{Cl}_{3}$ & [70] \\
\hline & & 1.890 & 2.846 & 433 & Mn2 & $\mathrm{Mn}_{8} \mathrm{O}_{10} \mathrm{Cl}_{3}$ & [70] \\
\hline \multicolumn{8}{|c|}{ Oxidation state of $\mathrm{Mn}:+2$} \\
\hline \multirow[t]{2}{*}{${ }^{\mathrm{b}} 6=[60-0 \mathrm{Cl}]$} & {$[(40)+(20)]$} & 2.215 & - & 6 & Mn1 & $\mathrm{Mn}_{2}\left[\mathrm{Bi}_{2} \mathrm{O}\right]\left(\mathrm{SeO}_{3}\right)_{4}$ & \\
\hline & & 2.226 & - & 39 & $\mathrm{Mn} 2$ & $\mathrm{Mn}^{\prime \prime} \mathrm{Mn}{ }^{\prime \prime \prime}\left(\mathrm{SeO}_{3}\right)_{2} \mathrm{Cl}$ & \\
\hline \multirow[t]{14}{*}{$6=[50-1 \mathrm{Cl}]$} & {$[(40)+(0+C l)]$} & 2.178 & 2.574 & 48 & Mn1 & $\left(\mathrm{NH}_{4}\right)_{2} \mathrm{MnB}_{2} \mathrm{P}_{3} \mathrm{O}_{11}(\mathrm{OH})_{2} \mathrm{Cl}$ & [71] \\
\hline & & 2.223 & 2.490 & 42 & Mn1 & $\mathrm{MnSb}_{2} \mathrm{O}_{3}(\mathrm{OH}) \mathrm{Cl}$ & [72] \\
\hline & & 2.218 & 2.654 & 86 & Mn1 & $\mathrm{Mn}_{2}\left(\mathrm{PO}_{4}\right) \mathrm{Cl}$ & [73] \\
\hline & & 2.198 & 2.475 & 25 & Mn1 & $\mathrm{Mn}_{3}\left(\mathrm{Sb}_{2} \mathrm{O}_{2}\right)\left(\mathrm{VO}_{4}\right)_{1.9}\left(\mathrm{SbO}_{3}\right)_{0.1} \mathrm{Cl}$ & [74] \\
\hline & & 2.168 & 2.919 & 152 & Mn1 & $\mathrm{Na}_{2} \mathrm{RbMn}_{3}\left(\mathrm{P}_{2} \mathrm{O}_{7}\right)_{2} \mathrm{Cl}$ & [75] \\
\hline & & 2.173 & 2.951 & 161 & $\mathrm{Mn} 1$ & $\mathrm{Na}_{2} \mathrm{CsMn}_{3}\left(\mathrm{P}_{2} \mathrm{O}_{7}\right)_{2} \mathrm{Cl}$ & [75] \\
\hline & & 2.171 & 2.570 & 46 & Mn1 & $\mathrm{Na}_{13} \mathrm{Mn}_{4} \mathrm{Se}_{6} \mathrm{~W}_{24} \mathrm{O}_{151} \mathrm{ClH}_{114}$ & [76] \\
\hline & & 2.173 & 2.978 & 175 & Mn3 & $\mathrm{Mn}_{3.5}\left(\mathrm{AsO}_{4}\right)_{2} \mathrm{Cl}$ & [77] \\
\hline & & 2.166 & 2.962 & 189 & Mn2 & $\mathrm{Mn}_{4}\left(\mathrm{TeO}_{3}\right)\left(\mathrm{SiO}_{4}\right) \mathrm{Cl}_{2}$ & [51] \\
\hline & & 2.234 & 2.557 & 44 & Mn2 & $\mathrm{Mn}_{5}\left(\mathrm{AsO}_{4}\right)_{3} \mathrm{Cl}$ & [77] \\
\hline & & 2.251 & 2.500 & 37 & $\mathrm{Mn} 2$ & $\mathrm{Mn}_{5}\left(\mathrm{PO}_{4}\right)_{3} \mathrm{Cl}_{0.9}(\mathrm{OH})_{0.1}$ & [78] \\
\hline & & 2.276 & 2.163 & 8 & Mn6 & $\mathrm{Mn}_{7} \mathrm{Fe}_{0.6} \mathrm{Mg}_{0.4} \mathrm{Si}_{6} \mathrm{O}_{15} \mathrm{Cl}_{2}(\mathrm{OH})_{8}$ & [79] \\
\hline & & 2.217 & 2.589 & 41 & Mn5 & $\mathrm{Mn}_{8} \mathrm{Si}_{6} \mathrm{O}_{24} \mathrm{ClH}_{9}$ & {$[79,80]$} \\
\hline & & 2.284 & 2.587 & 107 & Mn6 & $\mathrm{Mn}_{11}\left(\mathrm{AsO}_{4}\right)_{7} \mathrm{Cl}$ & {$[77]$} \\
\hline \multirow[t]{10}{*}{$6=[40-2 \mathrm{Cl}]$} & {$[(40)+(2 \mathrm{Cl})]$} & 2.115 & 2.648 & 129 & Mn1 & $\mathrm{CsMn}_{2}\left(\mathrm{~V}_{2} \mathrm{O}_{7}\right) \mathrm{Cl}$ & [81] \\
\hline & & 2.134 & 3.081 & 448 & Mn1 & $\mathrm{Mn}_{3}\left(\mathrm{~B}_{7} \mathrm{O}_{13}\right) \mathrm{Cl}$ & [82] \\
\hline & & 2.121 & 3.070 & 442 & $\mathrm{Mn} 2$ & $\mathrm{Mn}_{3}\left(\mathrm{~B}_{7} \mathrm{O}_{13}\right) \mathrm{Cl}$ & [82] \\
\hline & & 2.130 & 3.074 & 431 & Mn3 & $\mathrm{Mn}_{3}\left(\mathrm{~B}_{7} \mathrm{O}_{13}\right) \mathrm{Cl}$ & [82] \\
\hline & & 2.154 & 2.546 & 67 & Mn2 & $\mathrm{Mn}_{3}\left(\mathrm{Sb}_{2} \mathrm{O}_{2}\right)\left(\mathrm{VO}_{4}\right)_{1.9}\left(\mathrm{SbO}_{3}\right)_{0.1} \mathrm{Cl}_{2}$ & [74] \\
\hline & & 2.165 & 2.620 & 111 & $\mathrm{Mn} 2$ & $\mathrm{Na}_{2} \mathrm{RbMn}_{3}\left(\mathrm{P}_{2} \mathrm{O}_{7}\right)_{2} \mathrm{Cl}$ & {$[75]$} \\
\hline & & 2.171 & 2.641 & 123 & $\mathrm{Mn} 2$ & $\mathrm{Na}_{2} \mathrm{CsMn}_{3}\left(\mathrm{P}_{2} \mathrm{O}_{7}\right)_{2} \mathrm{Cl}$ & [75] \\
\hline & & 2.144 & 2.685 & 121 & $\mathrm{Mn} 2$ & $\mathrm{~K}_{2} \mathrm{CsMn}_{3}\left(\mathrm{P}_{2} \mathrm{O}_{7}\right)_{2} \mathrm{Cl}$ & [75] \\
\hline & & 2.244 & 2.489 & 25 & Mn4 & $\mathrm{Mn}_{3.5}\left(\mathrm{AsO}_{4}\right)_{2} \mathrm{Cl}$ & [77] \\
\hline & & 2.225 & 2.392 & 42 & Mn5 & $\mathrm{Mn}_{7} \mathrm{Fe}_{0.6} \mathrm{Mg}_{0.4} \mathrm{Si}_{6} \mathrm{O}_{15} \mathrm{Cl}_{2}(\mathrm{OH})_{8}$ & [79] \\
\hline \multirow[t]{7}{*}{$6=[40-2 \mathrm{Cl}]$} & {$[(30+C l)+(0+C l)]$} & 2.186 & 2.660 & 97 & Mn1 & $\mathrm{MnSm}\left(\mathrm{SeO}_{3}\right)_{2} \mathrm{Cl}$ & [49] \\
\hline & & 2.242 & 2.627 & 83 & Mn1 & $\mathrm{MnBi}\left(\mathrm{SeO}_{3}\right)_{2} \mathrm{Cl}$ & \\
\hline & & 2.114 & 2.731 & 165 & Mn1 & $\mathrm{Mn}_{3.5}\left(\mathrm{AsO}_{4}\right)_{2} \mathrm{Cl}$ & {$[77]$} \\
\hline & & 2.226 & 2.552 & 45 & $\mathrm{Mn} 2$ & $\mathrm{Mn}_{5}\left(\mathrm{SeO}_{3}\right)_{2} \mathrm{Cl}_{6}$ & \\
\hline & & 2.244 & 2.543 & 36 & Mn2 & $\mathrm{Mn}_{7} \mathrm{Fe}_{0.6} \mathrm{Mg}_{0.4} \mathrm{Si}_{6} \mathrm{O}_{15} \mathrm{Cl}_{2}(\mathrm{OH})_{8}$ & [79] \\
\hline & & 2.242 & 2.544 & 37 & Mn2 & $\mathrm{Mn}_{8} \mathrm{Si}_{6} \mathrm{O}_{24} \mathrm{ClH}_{9}$ & {$[79,80]$} \\
\hline & & 2.097 & 2.960 & 328 & Mn1 & $\mathrm{Mn}_{11}\left(\mathrm{AsO}_{4}\right)_{7} \mathrm{Cl}$ & {$[77]$} \\
\hline \multirow[t]{4}{*}{$6=[40-2 \mathrm{Cl}]$} & {$[(20+2 \mathrm{Cl})-\mathrm{cis}+(20)]$} & 2.193 & 2.500 & 40 & Mn1 & $\mathrm{CuMn}\left(\mathrm{HSeO}_{3}\right)_{2} \mathrm{Cl}_{2}\left(\mathrm{H}_{2} \mathrm{O}\right)_{4}$ & [83] \\
\hline & & 2.183 & 2.534 & 47 & Mn1 & $\mathrm{CsMnCl}_{3}\left(\mathrm{H}_{2} \mathrm{O}\right)_{2}$ & {$[84-86]$} \\
\hline & & 2.201 & 2.488 & 35 & Mn1 & $\mathrm{MnCl}_{2}\left(\mathrm{H}_{2} \mathrm{O}\right)_{4}$ & [87-89] \\
\hline & & 2.227 & 2.563 & 77 & $\mathrm{Mn} 2$ & $\mathrm{Mn}_{2}\left(\mathrm{PO}_{4}\right) \mathrm{Cl}$ & [73] \\
\hline $6=[40-2 \mathrm{Cl}]$ & {$[(20+C l)+(20+C l)]$} & 2.122 & 2.867 & 222 & Mn2 & $\mathrm{CsMn}_{2}\left(\mathrm{~V}_{2} \mathrm{O}_{7}\right) \mathrm{Cl}$ & [81] \\
\hline \multirow[t]{2}{*}{$6=[30-3 \mathrm{Cl}]$} & {$[(20+2 \mathrm{Cl})-c i s+(\mathrm{O}+\mathrm{Cl})]$} & 2.143 & 2.640 & 62 & Mn1 & $\mathrm{Mn}_{4}\left(\mathrm{Mn}_{5}, \mathrm{Bi}\right)\left(\mathrm{SeO}_{3}\right)_{8} \mathrm{Cl}_{5}$ & \\
\hline & & 2.130 & 2.623 & 68 & $\mathrm{Mn} 2$ & $\mathrm{Mn}_{4}\left(\mathrm{Mn}_{5}, \mathrm{Bi}\right)\left(\mathrm{SeO}_{3}\right)_{8} \mathrm{Cl}_{5}$ & \\
\hline $6=[30-3 \mathrm{Cl}]$ & {$[(20+2 \mathrm{Cl})-$ trans $+(\mathrm{O}+\mathrm{Cl})]$} & 2.335 & 2.629 & 217 & $\mathrm{Mn} 1$ & $\mathrm{Mn}_{4}\left(\mathrm{TeO}_{3}\right)\left(\mathrm{SiO}_{4}\right) \mathrm{Cl}_{2}$ & [51] \\
\hline \multirow[t]{4}{*}{$6=[20-4 \mathrm{Cl}]$} & {$[(4 \mathrm{Cl})+(20)]$} & 2.193 & 2.584 & 57 & Mn1 & $\mathrm{MnCl}_{2}\left(\mathrm{H}_{2} \mathrm{O}\right)_{2}$ & {$[90,91]$} \\
\hline & & 2.186 & 2.536 & 49 & Mn1 & $\mathrm{KMnCl}_{3}\left(\mathrm{H}_{2} \mathrm{O}\right)_{2}$ & {$[92,93]$} \\
\hline & & 2.216 & 2.539 & 43 & Mn1 & $\beta-\mathrm{RbMnCl}_{3}\left(\mathrm{H}_{2} \mathrm{O}\right)_{2}$ & {$[94,95]$} \\
\hline & & 2.048 & 2.648 & 142 & Mn1 & $\mathrm{Rb}_{2} \mathrm{Mn}\left(\mathrm{VO}_{3}\right)_{2} \mathrm{Cl}_{2}$ & [81] \\
\hline
\end{tabular}


Tab. 4 (continued)

\begin{tabular}{|c|c|c|c|c|c|c|c|}
\hline \multirow{2}{*}{$\begin{array}{l}\text { Coordination } \\
\text { number }\end{array}$} & \multirow[t]{2}{*}{ Geometry } & \multicolumn{3}{|c|}{ Average bond lengths and distortion } & \multirow[t]{2}{*}{ Site } & \multirow[t]{2}{*}{ Formula } & \multirow[t]{2}{*}{ Ref } \\
\hline & & $<M n-0>(\AA)$ & $<\mathrm{Mn}-\mathrm{Cl}>(\AA)$ & $\Delta_{d}, 10^{4}$ & & & \\
\hline & & 2.041 & 2.741 & 193 & Mn1 & $\mathrm{Cs}_{2} \mathrm{Mn}\left(\mathrm{VO}_{3}\right)_{2} \mathrm{Cl}_{2}$ & [81] \\
\hline & & 2.176 & 2.531 & 48 & Mn1 & $\mathrm{K}_{2} \mathrm{MnCl}_{4}\left(\mathrm{H}_{2} \mathrm{O}\right)_{2}$ & [96] \\
\hline & & 2.080 & 2.560 & 89 & Mn1 & $\mathrm{Rb}_{2} \mathrm{MnCl}_{4}\left(\mathrm{H}_{2} \mathrm{O}\right)_{2}$ & [97] \\
\hline & & 2.128 & 2.543 & 66 & Mn1 & $\mathrm{Cs}_{2} \mathrm{MnCl}_{4}\left(\mathrm{H}_{2} \mathrm{O}\right)_{2}$ & [97] \\
\hline & & 2.200 & 2.545 & 45 & Mn1 & $\left(\mathrm{NH}_{4}\right)_{2} \mathrm{MnCl}_{4}\left(\mathrm{H}_{2} \mathrm{O}\right)_{2}$ & [98] \\
\hline \multirow[t]{2}{*}{$6=[20-4 \mathrm{Cl}]$} & {$[(2 \mathrm{O}+2 \mathrm{Cl})-c i s+(2 \mathrm{Cl})]$} & 2.176 & 2.541 & 51 & Mn1 & $\alpha-\mathrm{RbMnCl}_{3}\left(\mathrm{H}_{2} \mathrm{O}\right)_{2}$ & [94] \\
\hline & & 2.157 & 2.594 & 119 & Mn3 & $\mathrm{Mn}_{5}\left(\mathrm{SeO}_{3}\right)_{2} \mathrm{Cl}_{6}$ & \\
\hline $6=[20-4 \mathrm{Cl}]$ & {$[(4 \mathrm{Cl})+(20)]$} & 2.073 & 2.594 & 107 & Mn1 & $\mathrm{Mn}_{5}\left(\mathrm{SeO}_{3}\right)_{2} \mathrm{Cl}_{6}$ & $\mathrm{a}$ \\
\hline \multirow[t]{3}{*}{$6=[10-5 \mathrm{Cl}]$} & {$[(0+3 \mathrm{Cl})+(2 \mathrm{Cl})]$} & 2.078 & 2.550 & 53 & Mn1 & $\mathrm{MnCl}_{2}\left(\mathrm{H}_{2} \mathrm{O}\right)$ & [99] \\
\hline & & 2.268 & 2.550 & 18 & Mn1 & $\mathrm{CrMnCl}_{5}\left(\mathrm{NH}_{3}\right)_{6}\left(\mathrm{H}_{2} \mathrm{O}\right)$ & [100] \\
\hline & & 2.259 & 2.540 & 20 & $\mathrm{Mn} 2$ & $\mathrm{CrMnCl}_{5}\left(\mathrm{NH}_{3}\right)_{6}\left(\mathrm{H}_{2} \mathrm{O}\right)$ & [100] \\
\hline
\end{tabular}

aThis work.

${ }^{\mathrm{b}} \mathrm{Mn}-\mathrm{O}$ bong lengths in $\mathrm{MnO}_{6}$ are given for the I and III compounds for comparison.

six-fold anionic environments of Mn cations in the crystal structures I-V. The remarkable versatility of the Mn coordination in five compounds reported herein encouraged us to investigate the mixed-ligand environments of Mn cations in the structures of all reported inorganic compounds. Table 4 provides an overview of the observed $\mathrm{MnO}_{n} \mathrm{Cl}_{m}$ polyhedra. Eleven and two stereochemically different mixed-ligand geometries correspond to $\mathrm{Mn}^{\mathrm{II}}$ and $\mathrm{Mn}^{\mathrm{III}}$ cations, respectively, while no mixed-ligand environments were found for $\mathrm{Mn}^{\mathrm{IV}}$ so far. All observed polyhedra can be described as octahedra with various degrees of distortion except the $\mathrm{Mn}$ coordination polyhedron in the structure of $\mathrm{CsMn}_{2}\left(\mathrm{~V}_{2} \mathrm{O}_{7}\right) \mathrm{Cl}$, which is rather a trigonal prism than an octahedron [81]. $\mathrm{MnO}_{4} \mathrm{Cl}_{2}$ octahedra are most common, whereas $\mathrm{MnOCl}_{5}$ configurations are very rare.

In order to quantify the degree of distortions for the mixed-ligand polyhedra, we used the $\Delta_{d}$ parameter defined previously by Alonso et al. for perovskites [101]. This parameter concerns the deviation of $\mathrm{Mn}-\mathrm{O} / \mathrm{Cl}$ distances with respect to its average value for each octahedron and can be calculated as follows $\Delta_{d}=(1 / 6) \cdot \Sigma_{n=1,6}\left[\left(d_{n}-\langle d\rangle\right) /\langle d\rangle\right]^{2}$, where $\langle d\rangle$ is the average $\mathrm{Mn}-\mathrm{O} / \mathrm{Cl}$ distance in a octahedron. Unsurprisingly, there is an increase of the distortion of polyhedra with the elongation of the $\mathrm{Mn}-\mathrm{Cl}$ distances. The geometries of the polyhedra show essential variabilities for each type of $\mathrm{MnO}_{n} \mathrm{Cl}_{m}$ polyhedra. In particular, two chloride anions in $\mathrm{MnO}_{4} \mathrm{Cl}_{2}$ octahedra may be located opposite to each other and complement the $\mathrm{MnO}_{4}$ squares $([(4 \mathrm{O})+(2 \mathrm{Cl})])$ (trans-position) or be in cis-position $([(3 \mathrm{O}+\mathrm{Cl})+(\mathrm{O}+\mathrm{Cl})]$ octahedra $)$. The average bond lengths in the mixed-ligand polyhedra for all the structures under consideration are: $\left\langle\mathrm{Mn}^{\mathrm{II}}-\mathrm{O}\right\rangle=2.180 \AA$ and $<\mathrm{Mn}{ }^{\mathrm{II}}-\mathrm{Cl}>=2.645 \AA$ A.

\section{Conclusion}

Five new compounds belonging to novel chemical families of materials (Mn selenite chlorides and Bi-Mn selenites and oxoselenites) have been synthesized and structurally characterized by single crystal X-ray diffraction analysis for the first time. Four of them (II-V) containing chloride anions have been prepared by the CVT method, whereas crystals of the compound I were grown hydrothermally. The combination of asymmetric selenite group with stereoactive lone pairs of electrons, chloride anions, transition-metal and bismuth cations provides an example of a promising chemical system for search of new materials with novel structure types. The crystal growth in the system is strongly dependent upon the synthesis conditions, which is manifested in the formation of three different phases from the same initial mixture with the only difference in a temperature regime of the applied thermal treatment. Hence, further efforts in the synthesis of novel Bi and Mn oxoselenites by the CVT method may be focused on the investigation of the temperature influence upon the crystal growth. The structural variety, complexity, and the presence of a transition metal in the new phases provide a broad field for the further studies of their physical properties. Nevertheless, the difficulties to choose the optimal experimental conditions for the preparation of sufficient amount of bulk phase should be considered.

Acknowledgements: This work was carried out within the project of the Russian Foundation for Basic Research through the grant 16-35-00191 mol_a for VMK. OIS thanks the President grant MD-5229.2018.5. We also thank an anonymous referee for his/her constructive comments and useful suggestions. 


\section{References}

[1] A. Choudhury, U. Kumar, C. N. R. Rao, Three-dimensional organically templated open-framework transition metal selenites. Angew. Chem. Int. Ed. 2002, 41, 158.

[2] S. V. Krivovichev, V. Kahlenberg, R. Kaindl, E. Mersdorf, I. G. Tananaev, B. F. Myasoedov, Nanoscale tubules in uranyl selenates. Angew. Chem. Int. Ed. Engl. 2005, 44, 1134.

[3] L.-D. Zhao, J. He, D. Berardan, Y. Lin, J.-F. Li, C.-W. Nan, N. Dragoe, BiCuSeO oxyselenides: new promising thermoelectric materials. Energy Environ. Sci. 2014, 7, 2900.

[4] V. M. Kovrugin, M. Colmont, C. Terryn, S. Colis, O. I. Siidra, S. V. Krivovichev, $\mathrm{O}$. Mentré, $\mathrm{pH}$-controlled pathway and systematic hydrothermal phase diagram for elaboration of synthetic lead nickel selenites. Inorg. Chem. 2015, 54, 2425.

[5] S. Y. Song, D. W. Lee, K. M. Ok, Rich structural chemistry in scandium selenium/tellurium oxides: mixed-valent seleniteselenates, $\mathrm{Sc}_{2}\left(\mathrm{SeO}_{3}\right)_{2}\left(\mathrm{SeO}_{4}\right)$ and $\mathrm{Sc}_{2}\left(\mathrm{TeO}_{3}\right)\left(\mathrm{SeO}_{3}\right)\left(\mathrm{SeO}_{4}\right)$, and ternary tellurite, $\mathrm{Sc}_{2}\left(\mathrm{TeO}_{3}\right)_{3}$. Inorg. Chem. 2014, 53, 7040.

[6] P. S. Berdonosov, E. S. Kuznetsova, V. A. Dolgikh, Transition metal selenite halides: a fascinating family of magnetic compounds. Crystals 2018, 8, 159.

[7] A. Aliev, V. M. Kovrugin, M. Colmont, C. Terryn, M. Huvé, O. I. Siidra, S. V. Krivovichev, O. Mentré, Revised bismuth chloroselenite system: evidence of a noncentrosymmmetric structure with a giant unit cell. Cryst. Growth Des. 2014, 14, 3026.

[8] V. M. Kovrugin, M. Colmont, O. I. Siidra, V. V. Gurzhiy, S. V. Krivovichev, O. Mentré, Pathways for synthesis of new selenium-containing oxo-compounds: chemical vapor transport reactions, hydrothermal techniques and evaporation method. J. Cryst. Growth 2017, 457, 307.

[9] D. O. Charkin, E. V. Nazarchuk, S. Y. Stefanovich, E. B. Djangurazov, A. I. Zadoya, O. I. Siidra, Polar $\mathrm{BaCl}\left(\mathrm{ClO}_{4}\right) \cdot \mathrm{H}_{2} \mathrm{O}$ layered chloride perchlorate. Inorg. Chem. Commun. 2017, 84, 174.

[10] V. M. Kovrugin, M. Colmont, O. I. Siidra, O. Mentré, A. Al-Shuray, V. V. Gurzhiy, S. V. Krivovichev, Oxocentered Cu(ii) lead selenite honeycomb lattices hosting $\mathrm{Cu}(\mathrm{i}) \mathrm{Cl}_{2}$ groups obtained by chemical vapor transport reactions. Chem. Commun. 2015, 51, 9563.

[11] V. M. Kovrugin, M. Colmont, O. Mentré, O. I. Siidra, S. V. Krivovichev, Dimers of oxocentred $\left[\mathrm{OCu}_{4}\right]^{6+}$ tetrahedra in two novel copper selenite chlorides, $\mathrm{K}\left[\mathrm{Cu}_{3} \mathrm{O}\right]\left(\mathrm{SeO}_{3}\right)_{2} \mathrm{Cl}$ and $\mathrm{Na}_{2}\left[\mathrm{Cu}_{7} \mathrm{O}_{2}\right]$ $\left(\mathrm{SeO}_{3}\right)_{4} \mathrm{Cl}_{4}$, and related minerals and inorganic compounds. Mineral. Mag. 2016, 80, 227.

[12] V. M. Kovrugin, S. V. Krivovichev, O. Mentré, M. Colmont, [ $\mathrm{NaCl}]$ $\left[\mathrm{Cu}\left(\mathrm{HSeO}_{3}\right)_{2}\right], \mathrm{NaCl}$-intercalated $\mathrm{Cu}\left(\mathrm{HSeO}_{3}\right)_{2}$ : synthesis, crystal structure and comparison with related compounds. Z. Kristallogr. 2015, 230, 573.

[13] P. S. Berdonosov, O. Janson, A. V Olenev, S. V. Krivovichev, H. Rosner, V. A. Dolgikh, A. A. Tsirlin, Crystal structures and variable magnetism of $\mathrm{PbCu}_{2}\left(X_{3}\right)_{2} \mathrm{Cl}_{2}$ with $X=\mathrm{Se}$, Te. Dalton Trans. 2013, 42, 9547.

[14] O. Janson, A. A. Tsirlin, E. S. Osipova, P. S. Berdonosov, A. V. Olenev, V. A. Dolgikh, H. Rosner, $\mathrm{CaCu}_{2}\left(\mathrm{SeO}_{3}\right)_{2} \mathrm{Cl}_{2}$ : spin-1/2 Heisenberg chain compound with complex frustrated interchain couplings. Phys. Rev. B 2011, 83, 144423.

[15] D. I. Badrtdinov, E. S. Kuznetsova, V. Y. Verchenko, P. S. Berdonosov, V. A. Dolgikh, V. V. Mazurenko, A. A. Tsirlin, Magnetism of coupled spin tetrahedra in ilinskite-type $\mathrm{KCu}_{5} \mathrm{O}_{2}\left(\mathrm{SeO}_{3}\right)_{2} \mathrm{Cl}_{3}$. Sci. Rep. 2018, 8, 2379.
[16] P. S. Berdonosov, E. S. Kuznetsova, V. A. Dolgikh, A. V. Sobolev, I. A. Presniakov, A. V. Olenev, B. Rahaman, T. Saha-Dasgupta, K. V. Zakharov, E. A. Zvereva, O. S. Volkova, A. N. Vasiliev, Crystal structure, physical properties, and electronic and magnetic structure of the spin $\mathrm{S}=5 / 2$ zigzag chain compound $\mathrm{Bi}_{2} \mathrm{Fe}\left(\mathrm{SeO}_{3}\right)_{2} \mathrm{OCl}_{3}$. Inorg. Chem. 2014, 53, 5830.

[17] M. M. Markina, K. V. Zakharov, E. A. Zvereva, R. S. Denisov, P. S. Berdonosov, V. A. Dolgikh, E. S. Kuznetsova, A. V. Olenev, A. N. Vasiliev, Static and dynamic magnetic properties of two synthetic francisites $\mathrm{Cu}_{3} \mathrm{La}\left(\mathrm{SeO}_{3}\right)_{2} \mathrm{O}_{2} X(X=\mathrm{Br}$ and $\mathrm{Cl})$. Phys. Chem. Miner. 2017, 44, 277.

[18] E. Constable, S. Raymond, S. Petit, E. Ressouche, F. Bourdarot, J. Debray, M. Josse, O. Fabelo, H. Berger, S. DeBrion, V. Simonet, Magnetic and dielectric order in the kagomelike francisite $\mathrm{Cu}_{3} \mathrm{Bi}\left(\mathrm{SeO}_{3}\right)_{2} \mathrm{O}_{2} \mathrm{Cl}$. Phys. Rev. B 2017, 96, 014413.

[19] V. Gnezdilov, Y. Pashkevich, P. Lemmens, V. Kurnosov, P. Berdonosov, V. Dolgikh, E. Kuznetsova, V. Pryadun, K. Zakharov, A. Vasiliev, Lattice and magnetic instabilities in $\mathrm{Cu}_{3} \mathrm{Bi}\left(\mathrm{SeO}_{3}\right)_{2} \mathrm{O}_{2} X(X=\mathrm{Br}, \mathrm{Cl})$. Phys. Rev. B 2017, 96, 115144.

[20] H. C. Wu, K. D. Chandrasekhar, J. K. Yuan, J. R. Huang, J.-Y. Lin, H. Berger, H. D. Yang, Anisotropic spin-flip-induced multiferroic behavior in kagome $\mathrm{Cu}_{3} \mathrm{Bi}\left(\mathrm{SeO}_{3}\right)_{2} \mathrm{O}_{2} \mathrm{Cl}$. Phys. Rev. B 2017, 95, 125121.

[21] D. A. Prishchenko, A. A. Tsirlin, V. Tsurkan, A. Loidl, A. Jesche, V. G. Mazurenko, Antiferroelectric instability in the kagome francisite $\mathrm{Cu}_{3} \mathrm{Bi}\left(\mathrm{SeO}_{3}\right)_{2} \mathrm{O}_{2} X(X=\mathrm{Cl}, \mathrm{Br})$. Phys. Rev. B 2017, 95 , 064102.

[22] K. V. Zakharov, E. A. Zvereva, M. M. Markina, M. I. Stratan, E. S. Kuznetsova, S. F. Dunaev, P. S. Berdonosov, V. A. Dolgikh, A. V. Olenev, S. A. Klimin, L. S. Mazaev, M. A. Kashchenko, M. A. Ahmed, A. Banerjee, S. Bandyopadhyay, A. Iqbal, B. Rahaman, T. Saha-Dasgupta, A. N. Vasiliev, Magnetic, resonance, and optical properties of $\mathrm{Cu}_{3} \mathrm{Sm}\left(\mathrm{SeO}_{3}\right)_{2} \mathrm{O}_{2} \mathrm{Cl}$ : a rare-earth francisite compound. Phys. Rev. B 2016, 94, 054401.

[23] K. V. Zakharov, E. A. Zvereva, P. S. Berdonosov, E. S. Kuznetsova, V. A. Dolgikh, L. Clark, C. Black, P. Lightfoot, W. Kockelmann, Z. V. Pchelkina, S. V. Streltsov, O. S. Volkova, A. N. Vasiliev, Thermodynamic properties, electron spin resonance, and underlying spin model in $\mathrm{Cu}_{3} \mathrm{Y}\left(\mathrm{SeO}_{3}\right)_{2} \mathrm{O}_{2} \mathrm{Cl}$. Phys. Rev. B 2014, 90, 214417.

[24] H. C. Wu, W. J. Tseng, P. Y. Yang, K. D. Chandrasekhar, H. Berger, H. D. Yang, Anisotropic pressure effects on the Kagome $\mathrm{Cu}_{3} \mathrm{Bi}\left(\mathrm{SeO}_{3}\right)_{2} \mathrm{O}_{2} \mathrm{Cl}$ metamagnet. J. Phys. D: Appl. Phys. 2017, 50, 265002.

[25] V. M. Kovrugin, E. E. Gordon, E. E. Kasapbasi, M.-H. Whangbo, M. Colmont, O. I. Siidra, S. Colis, S. V. Krivovichev, O. Mentré, Bonding scheme, hydride character, and magnetic paths of $\left(\mathrm{HPO}_{3}\right)^{2-}$ versus $\left(\mathrm{SeO}_{3}\right)^{2-}$ building units in solids. J. Phys. Chem. C 2016, 120, 1650.

[26] S. V. Krivovichev, O. Mentré, O. I. Siidra, M. Colmont, S. K. Filatov, Anion-centered tetrahedra in inorganic compounds. Chem. Rev. 2013, 113, 6459.

[27] A. Aliev, J. Olchowka, M. Colmont, E. Capoen, C. Wickleder, O. Mentré, New $\left[\mathrm{PbBi}_{2} \mathrm{O}_{4}\right]\left[\mathrm{Bi}_{2} \mathrm{O}_{2}\right] \mathrm{Cl}_{2}$ and $\left[\mathrm{Pb}_{n} \mathrm{Bi}_{10-n} \mathrm{O}_{13}\right]\left[\mathrm{Bi}_{2} \mathrm{O}_{2}\right]_{n} \mathrm{Cl}_{4+n}$ series by association of sizable subunits: relationship with Arppe's compound $\mathrm{Bi}_{24} \mathrm{O}_{31} \mathrm{Cl}_{10}$ and luminescence properties. Inorg. Chem. 2013, 52, 8427.

[28] M. Lü, A. Aliev, J. Olchowka, M. Colmont, M. Huvé, C. Wickleder, 0 . Mentré, Multidimensional open-frameworks: combinations of one-dimensional channels and two-dimensional layers in novel Bi/M oxo-chlorides. Inorg. Chem. 2014, 53, 528. 
[29] M. S. Kozin, A. Aliev, M. Colmont, O. Mentré, O. I. Siidra, S. V. Krivovichev, Novel bismuth oxophosphate halides $\left[\mathrm{Bi}_{8} \mathrm{O}_{8}\right]\left[\mathrm{BiO}_{2}\right]$ $\left(\mathrm{PO}_{4}\right)_{2} X(X=\mathrm{Cl}, \mathrm{Br})$ based on oxocentered $2 \mathrm{D}$ blocks and their relationships to the Aurivillius phases. J. Solid State Chem. 2013, 199, 56.

[30] M.-L. Liang, C.-L. Hu, F. Kong, J.-G. Mao, $\mathrm{BiFSeO}_{3}$ : an excellent SHG material designed by aliovalent substitution. J. Am. Chem. Soc. 2016, 138, 9433.

[31] L. Geng, Q. Li, C.-Y. Meng, K. Dai, H.-Y. Lu, C.-S. Lin, W.-D. Cheng, $\mathrm{BaBi}\left(\mathrm{SeO}_{3}\right)_{2} \mathrm{Cl}$ : a new polar material showing high second-harmonic generation efficiency enhanced by constructive alignment of chloride ions. J. Mater. Chem. C 2015, 3, 12290.

[32] A. Aliev, M. Huvé, S. Colis, M. Colmont, A. Dinia, O. Mentré, Two-dimensional antiferromagnetism in the $\left[\mathrm{Mn}_{3+x} \mathrm{O}_{7}\right]\left[\mathrm{Bi}_{4} \mathrm{O}_{4.5-\gamma}\right]$ compound with a maple-leaf lattice. Angew. Chem. Int. Ed. 2012, 51, 9393.

[33] C. C. Chou, C. L. Huang, S. Mukherjee, Q. Y. Chen, H. Sakurai, A. A. Belik, E. Takayama-Muromachi, H. D. Yang, Multiple magnetic transitions in multiferroic $\mathrm{BiMnO}_{3}$. Phys. Rev. B 2009, 80, 184426.

[34] M. Wildner, Crystal structure of $\mathrm{Mn}(\mathrm{II}) \mathrm{Mn}(\mathrm{III})_{2} \mathrm{O}\left(\mathrm{SeO}_{3}\right)_{3}$. J. Solid State Chem. 1994, 113, 252.

[35] O. Rademacher, H. Göbel, H. Oppermann, Crystal structure of bismuth selenite, $\mathrm{Bi}_{2}\left(\mathrm{SeO}_{3}\right)_{3}$. Z. Kristallogr. NCS 2000, 215, 339.

[36] K. G. Keramidas, G. P. Voutsas, P. I. Rentzeperis, The crystal structure of BiOCl. Z. Kristallogr. Cryst. Mater. 1993, 205, 35.

[37] D. O. Charkin, R. A. Kayukov, K. A. Zagidullin, O. I. Siidra, Chemical vapor transport and solid-state exchange synthesis of new copper selenite bromides. Solid State Sci. 2017, 64, 109.

[38] S. A. Ibragimov, P. S. Berdonosov, V. A. Dolgikh, D. Q. Huong, H. Oppermann, Crystal structure and SHG characterization of $\gamma$-BiSeO ${ }_{3} \mathrm{Cl}$. Inorg. Mater. 2002, 38, 1291.

[39] G. M. Sheldrick, Crystal structure refinement with SHELXL. Acta Crystallogr. C 2015, C71, 3.

[40] N. E. Brese, M. O'Keeffe, Bond-valence parameters for solids. Acta Crystallogr. B 1991, B47, 192.

[41] S. V. Krivovichev, Derivation of bond-valence parameters for some cation-oxygen pairs on the basis of empirical relationships between $\mathrm{r} O \mathrm{and}$ b. Z. Kristallogr. 2012, 227, 575.

[42] J. Geb, M. Jansen, $\mathrm{Bi}_{2} \mathrm{AuO}_{5}$ and $\mathrm{Bi}_{4} \mathrm{Au}_{2} \mathrm{O}_{9}$, two novel ternary oxoaurates. J. Solid State Chem. 1996, 122, 364.

[43] A. K. Padhi, K. S. Nanjundaswamy, J. B. Goodenough, Phosphoolivines as positive-electrode materials for rechargeable lithium batteries. J. Electrochem. Soc. 1997, 144, 1188.

[44] H. Xiang, C. Lee, H.-J. Koo, X. Gong, M.-H. Whangbo, Magnetic properties and energy-mapping analysis. Dalton Trans. 2013, 42, 823.

[45] H. Effenberger, The Bi(III)-selenite $\left(\mathrm{Bi}_{2} \mathrm{O}\right) \mathrm{Cu}\left(\mathrm{SeO}_{3}\right)_{3} \cdot \mathrm{H}_{2} \mathrm{O}$. J. Alloys Comp. 1998, 281, 152.

[46] J. Wontcheu, T. Schleid, $\mathrm{Tb}_{2} \mathrm{Se}_{2} \mathrm{O}_{7}$ : terbium(III) oxide oxoselenate(IV) according to $\mathrm{Tb}_{2} \mathrm{O}\left[\mathrm{SeO}_{3}\right]_{2}$ with a "lone-pair" channel structure. Z. Anorg. Allg. Chem. 2002, 628, 1941.

[47] J. Wontcheu, T. Schleid, $\mathrm{Tb}_{3} \mathrm{O}_{2} \mathrm{Cl}\left[\mathrm{SeO}_{3}\right]_{2}$ and $\mathrm{Tb}_{5} \mathrm{O}_{4} \mathrm{Cl}_{3}\left[\mathrm{SeO}_{3}\right]_{2}$ : oxide chloride oxoselenates(IV) of trivalent terbium with "lone-pair" channel or layer structures. Z. Anorg. Allg. Chem. 2005, 631, 309.

[48] S. Zitzer, F. Schleifenbaum, T. Schleid, Synthesis, crystal structure and spectroscopic properties of $\mathrm{Y}_{3} \mathrm{O}_{2} \mathrm{Cl}\left[\mathrm{SeO}_{3}\right]_{2}: \mathrm{Eu}^{3+}$. Z. Kristallogr. 2011, 226, 651.

[49] M. S. Wickleder, M. Ben Hamida, $\mathrm{CoSm}\left(\mathrm{SeO}_{3}\right)_{2} \mathrm{Cl}, \mathrm{CuGd}\left(\mathrm{SeO}_{3}\right)_{2} \mathrm{Cl}$, $\mathrm{MnSm}\left(\mathrm{SeO}_{3}\right)_{2} \mathrm{Cl}, \mathrm{CuGd}_{2}\left(\mathrm{SeO}_{3}\right)_{4}$ und $\mathrm{CuSm}_{2}\left(\mathrm{SeO}_{3}\right)_{4}$ : Übergangsmetallhaltige Selenite von Samarium und Gadolinum. Z. Anorg. Allg. Chem. 2003, 629, 556.
[50] I. Zimmermann, M. Johnsson, A synthetic route toward layered materials: introducing stereochemically active lone-pairs into transition metal oxohalides. Cryst. Growth Des. 2014, 14, 5252.

[51] I. Zimmermann, R. K. Kremer, M. Johnsson, Two isostructural layered oxohalide compounds containing $\mathrm{Mn}^{2+}$, $\mathrm{Te}^{4+}$ and $\mathrm{Si}^{4+}$; crystal structure and magnetic susceptibility. J. Solid State Chem. 2014, 218, 6.

[52] J. Richter, J. Schulenburg, A. Honecker, Quantum magnetism in two dimensions: from semi-classical Neel order to magnetic disorder, in Quantum Magnetism (Eds. U. Schollwöck, J. Richter, D. J. J. Farnell and R. F. Bishop), Springer-Verlag, Berlin, Heidelberg, pp. 85-153, 2004.

[53] O. Smirnova, M. Azuma, N. Kumada, Y. Kusano, M. Matsuda, Y. Shimakawa, T. Takei, Y. Yonesaki, N. Kinomura, Synthesis, crystal structure, and magnetic properties of $\mathrm{Bi}_{3} \mathrm{Mn}_{4} \mathrm{O}_{12}\left(\mathrm{NO}_{3}\right)$ oxynitrate comprising $\mathrm{S}=3 / 2$ honeycomb lattice. J. Am. Chem. Soc. 2009, 131, 8313.

[54] S. W. Kim, Z. Deng, Z. Fischer, S. H. Lapidus, P. W. Stephens, M.-R. Li, M. Greenblatt, Structure and magnetic behavior of layered honeycomb tellurates, $\mathrm{Bi} M(\mathrm{III}) \mathrm{TeO}_{6}(M=\mathrm{Cr}, \mathrm{Mn}, \mathrm{Fe})$. Inorg. Chem. 2016, 55, 10229.

[55] S. V. Krivovichev, Structural complexity of minerals: information storage and processing in the mineral world. Mineral. Mag. 2013, 77, 275.

[56] S. V. Krivovichev, Topological complexity of crystal structures: quantitative approach. Acta Crystallogr. A 2012, A68, 393.

[57] S. V. Krivovichev, Ladders of information: what contributes to the structural complexity of inorganic crystals. Z. Kristallogr. Cryst. Mater. 2018, 233, 155.

[58] V. A. Blatov, A. P. Shevchenko, D. M. Proserpio, Applied topological analysis of crystal structures with the program package ToposPro. Cryst. Growth Des. 2014, 14, 3576.

[59] S. V. Krivovichev, Which inorganic structures are the most complex? Angew. Chem. Int. Ed. 2014, 53, 654.

[60] D. O. Charkin, S. Zitzer, S. Greiner, S. G. Dorofeev, A. V. Olenev, P. S. Berdonosov, T. Schleid, V. A. Dolgikh, Synthesis, structures, and luminescent properties of sodium rare-earth metal(III) chloride oxotellurates(IV), $\mathrm{Na}_{2} \mathrm{Ln}_{3} \mathrm{Cl}_{3}\left[\mathrm{TeO}_{3}\right]_{4}(\mathrm{Ln}=\mathrm{Sm}$, Eu, Gd, Tb, Dy, and Ho). Z. Anorg. Allg. Chem. 2017, 643, 1654.

[61] F. Abraham, O. Cousin, O. Mentré, E. M. Ketatni, Crystal structure approach of the disordered new compounds $\mathrm{Bi} \sim_{1.2} M \sim_{1.2} P_{5.5}(M=M n, C 0, Z n)$ : the role of oxygen-centered tetrahedra linkage in the structure of bismuth-transition metal oxy-phosphates. J. Solid State Chem. 2002, 167, 168.

[62] S. Neov, V. Marinova, M. Reehuis, R. Sonntag, Neutrondiffraction study of $\mathrm{Bi}_{12} M_{20}$ single crystals with sillenite structure $\left(M=\mathrm{Si}, \mathrm{Si}_{0.995} \mathrm{Mn}_{0.005}, \mathrm{Bi}_{0.53} \mathrm{Mn}_{0.47}\right)$. Appl. Phys. A 2002, 74, s1016.

[63] A. Aliev, D. Endara, M. Huvé, M. Colmont, P. Roussel, L. Delevoye, T. T. Tran, P. S. Halasyamani, O. Mentré, Labile degree of disorder in bismuth-oxophosphate compounds: illustration through three new structural types. Inorg. Chem. 2014, 53, 861.

[64] M. Colmont, D. Endara, A. Aliev, C. Terryn, M. Huvé, O. Mentré, $\mathrm{Bi}_{2} \mathrm{O}_{3}-\mathrm{CuO}-\mathrm{P}_{2} \mathrm{O}_{5}$ system: two novel compounds built from the intergrowths oxocentered polycationic 1D-ribbons. J. Solid State Chem. 2013, 203, 266.

[65] D. Endara, M. Colmont, M. Huvé, G. Tricot, L. Carpentier, 0. Mentré, Novel tailormade $\mathrm{Bi}_{4} \mathrm{MO}_{4}\left(\mathrm{PO}_{4}\right)_{2}$ structural type $(M=\mathrm{Mg}$, Zn). Inorg. Chem. 2012, 51, 4438. 
[66] D. Endara, M. Colmont, M. Huvé, F. Capet, J. Lejay, P. Aschehoug, O. Mentré, Inorganic polar blocks into controlled acentric assemblies. Inorg. Chem. 2012, 51, 9557.

[67] M. Colmont, M. Huvé, E. M. Ketatni, F. Abraham, O. Mentré, Double $(n=2)$ and triple $(n=3)\left[M_{4} \mathrm{Bi}_{2 n-2} \mathrm{O}_{2 n}\right]^{x+}$ polycationic ribbons in the new $\mathrm{Bi} \sim{ }_{3} \mathrm{Cd} \sim{ }_{3.72} \mathrm{M} \sim{ }_{1.28} \mathrm{O}_{5}\left(\mathrm{PO}_{4}\right)_{3}$ oxyphosphate (M=Co, Cu, Zn). J. Solid State Chem. 2003, 176, 221.

[68] X. Mo, S.-J. Hwu, Salt-inclusion synthesis of $\mathrm{Ba}_{2} \mathrm{MnSi}_{2} \mathrm{O}_{7} \mathrm{Cl}$. A fresnoite-type polar framework containing the acentric $\left[\mathrm{Si}_{2} \mathrm{O}_{7}\right]^{6-}$ polyanion in the anti- $\mathrm{ReO}_{3}$ type $\left[\left(\mathrm{Ba}_{2} \mathrm{Mn}\right) \mathrm{Cl}\right]^{6+}$ cage. Inorg. Chem. 2003, 42, 3978.

[69] P. Euzen, P. Palvadeau, M. Queignec, J. Rouxel, Preparation et caracterisation de l'oxychlorure mixte $\mathrm{FeMn}_{7} \mathrm{O}_{10} \mathrm{Cl}_{3}$. C. R. Acad. Sci., Ser. II: Mec., Phys., Chim., Sci. Terre Univers. 1991, 312, 367.

[70] G. Buisson, Structure cristalline d'un oxychlorure de manganèse, $\mathrm{Mn}_{8} \mathrm{O}_{10} \mathrm{Cl}_{3}$. Acta Crystallogr. B 1977, 33, 1031.

[71] K. Förg, H. A. Höppe, Synthesis, crystal structure, optical, magnetic and thermal properties of $\left(\mathrm{NH}_{4}\right)_{2} \mathrm{Mn}\left[\mathrm{B}_{2} \mathrm{P}_{3} \mathrm{O}_{11}(\mathrm{OH})_{2}\right] \mathrm{Cl}$. Z. Anorg. Allg. Chem. 2015, 641, 1009.

[72] L. Geng, Q. Li, H. Lu, K. Dai, P. S. Halasyamani, Sb-based antiferromagnetic oxychlorides: $\mathrm{MSb}_{2} \mathrm{O}_{3}(\mathrm{OH}) \mathrm{Cl}(M=\mathrm{Mn}, \mathrm{Fe}, \mathrm{Co})$ with 2D spin-dimer structures. Dalton Trans. 2016, 45, 18183.

[73] J. R. Rea, E. Kostiner, The crystal structure of manganese chlorophosphate, $\mathrm{Mn}_{2}\left(\mathrm{PO}_{4}\right) \mathrm{Cl}$. Acta Crystallogr. B 1972, 28, 2505.

[74] I. Zimmermann, M. Johnsson, Synthesis and crystal structure of $\mathrm{Mn}_{3}\left(\mathrm{Sb}_{2} \mathrm{O}_{2}\right)\left(\mathrm{VO}_{4}\right)_{2-x}\left(\mathrm{SbO}_{3}\right)_{x} \mathrm{Cl}_{2}(0.08<x<0.13)$, a vanadium oxochloride with a $\mathrm{V}^{\mathrm{V}}$ - Sb"l' split position. Z. Anorg. Allg. Chem. 2015, 641, 421.

[75] J. Gao, J. Li, D. Sulejmanovic, S.-J. Hwu, $M_{3}\left(\mathrm{P}_{2} \mathrm{O}_{7}\right)^{22-}$-type open frameworks featuring $\left[\mathrm{M}_{2} \mathrm{O}_{8}\right]$ and $\left[\mathrm{M}_{3} \mathrm{O}_{12}\right]$ multinuclear transition-metal oxide units. Serendipitous synthesis of six polymorphic salt-inclusion magnetic solids: $\mathrm{Na}_{2} \mathrm{M}_{3}\left(\mathrm{P}_{2} \mathrm{O}_{7}\right)_{2} \cdot \mathrm{ACl}$ $(M=\mathrm{Mn}, \mathrm{Fe} ; A=\mathrm{Rb}, \mathrm{Cs})$ and $\mathrm{K}_{2} \mathrm{M}_{3}\left(\mathrm{P}_{2} \mathrm{O}_{7}\right) \cdot \mathrm{CsCl}(\mathrm{M}=\mathrm{Fe}, \mathrm{Mn})$. Inorg. Chem. 2015, 54, 1136.

[76] I. V. Kalinina, E. V. Peresypkina, N. V. Izarova, F. M. Nkala, U. Kortz, N. B. Kompankov, N. K. Moroz, M. N. Sokolov, Cyclic tungstoselenites based on $\left\{\mathrm{Se}_{2} \mathrm{~W}_{12}\right\}$ units. Inorg. Chem. 2014, 53, 2076.

[77] M. Weil, R. K. Kremer, Crystal growth and crystal structures of six novel phases in the $\mathrm{Mn} / \mathrm{As} / \mathrm{O} / \mathrm{Cl}(\mathrm{Br})$ system, as well as magnetic properties of $\alpha-\mathrm{Mn}_{3}\left(\mathrm{AsO}_{4}\right)_{2}$. J. Solid State Chem. 2017, 245, 115.

[78] G. Engel, J. Pretzsch, V. Gramlich, W. H. Baur, The crystal structure of hydrothermally grown manganese chlorapatite, $\mathrm{Mn}_{5}\left(\mathrm{PO}_{4}\right)_{3} \mathrm{Cl}_{0.9}(\mathrm{OH})_{0.1}$. Acta Crystallogr. B 1975, 31, 1854.

[79] T. Ozawa, Y. Takeuchi, T. Takahata, G. Donnay, J. D. H. Donnay, The pyrosmalite group of minerals; II, the layer structure of mcgillite and friedelite. Can. Mineral. 1983, 21, 7.

[80] T. Kato, I. Watanabe, The crystal structures of schallerite and friedelite (in Japanese). Yamaguchi Univ., Coll. Arts Bull. 1992, 26, 51 .

[81] W. L. Queen, J. P. West, S.-J. Hwu, D. G. VanDerveer, M. C. Zarzyczny, R. A. Pavlick, The versatile chemistry and noncentrosymmetric crystal structures of salt-inclusion vanadate hybrids. Angew. Chem. Int. Ed. 2008, 47, 3791.

[82] F. Kubel, O. Crottaz, Crystal structure of manganese chlorine boracite, $\mathrm{Mn}_{3} \mathrm{~B}_{7} \mathrm{O}_{13} \mathrm{Cl}$. Z. Kristallogr. Cryst. Mater. 1996, 211, 924.
[83] A.-M. Lafront, J.-C. Trombe, J. Bonvoisin, 'Layered hydrogenselenites' II. Synthesis, structure studies and magnetic properties of a novel series of bimetallic hydrogenselenites: $\left[\mathrm{Cu}\left(\mathrm{HSeO}_{3}\right)_{2} \mathrm{MCl}_{2}\left(\mathrm{H}_{2} \mathrm{O}\right)_{4}\right], \mathrm{M}(\mathrm{II})=\mathrm{Mn}, \mathrm{Co}, \mathrm{Ni}, \mathrm{Cu}, \mathrm{Zn}$. Inorg. Chim . Acta 1995, 238, 15.

[84] S. J. Jensen, P. Andersen, S. E. Rasmussen, The crystal structure of $\mathrm{CsMnCl}_{3} \cdot 2 \mathrm{H}_{2}$ O. Acta Chem. Scand. 1962, 16, 1890.

[85] W. Massa, O. V. Yakubovich, O. V. Dimitrova, Redetermination of $\mathrm{Cs}\left[\mathrm{MnCl}_{3}\left(\mathrm{H}_{2} \mathrm{O}\right)_{2}\right]$. Acta Crystallogr. E 2007, 63, i24.

[86] I.-H. Oh, J.-E. Kim, J. Koo, J. M. S. Park, Refinement of cesium diaquatrichloromanganate(II), $\mathrm{CsMnCl}_{3} \cdot 2\left(\mathrm{H}_{2} \mathrm{O}\right)$ by neutron diffraction, $\mathrm{Cl}_{3} \mathrm{CsH}_{4} \mathrm{MnO}_{2}$. Z. Kristallogr. New Cryst. Struct. 2014, 229, 265.

[87] A. Zalkin, J. D. Forrester, D. H. Templeton, The crystal structure of manganese dichloride tetrahydrate. Inorg. Chem. 1964, 3, 529.

[88] Z. M. El Saffar, G. M. Brown, The structure of manganese dichloride tetrahydrate: a neutron diffraction study. Acta Crystallogr. B 1971, 27, 66.

[89] I.-C. Hwang, K. Ha, Refinement of crystal structure of tetraaquamanganese(II) dichloride, $\mathrm{Mn}_{\left(\mathrm{H}_{2} \mathrm{O}\right.}{ }_{4} \mathrm{Cl}_{2}$. Z. Kristallogr. New Cryst. Struct. 2009, 224, 517.

[90] B. K. Vainshtein, Crystal structure of $\mathrm{MnCl}_{2} \cdot 2 \mathrm{H}_{2} \mathrm{O}$ (in Russian). Dokl. Akad. Nauk SSSR 1952, 83, 227.

[91] B. Morosin, E. J. Graeber, Crystal structures of manganese(II) and iron(II) chloride dihydrate. J. Chem. Phys. 1965, 42, 898.

[92] S. J. Jensen, The crystal structure of $\mathrm{KMnCl}_{3}\left(\mathrm{H}_{2} \mathrm{O}\right)_{2}$. Acta Chem. Scand. 1968, 22, 641.

[93] F. Birkelund, S. J. Jensen, Neutron diffraction study of $\mathrm{KMnCl}_{3}\left(\mathrm{H}_{2} \mathrm{O}\right)_{2}$. Acta Chem. Scand. 1972, 26, 1358.

[94] S. J. Jensen, The crystal structures of alpha- and of beta-RbM$\mathrm{nCl}_{3} \cdot 2 \mathrm{H}_{2}$ O. Acta Chem. Scand. 1967, 21, 889.

[95] S. J. Jensen, Neutron diffraction study of beta- $\mathrm{RbMnCl}_{3} \cdot 2 \mathrm{H}_{2} \mathrm{O}$. Acta Chem. Scand. 1970, 24, 3422.

[96] S. J. Jensen, The crystal structure of $\mathrm{K}_{2} \mathrm{MnCl}_{4}\left(\mathrm{H}_{2} \mathrm{O}\right)_{2}$. Acta Chem. Scand. 1968, 22, 647.

[97] S. J. Jensen, The crystal structures of $\mathrm{Cs}_{2} \mathrm{MnCl}_{4}\left(\mathrm{H}_{2} \mathrm{O}\right)_{2}$ and $\mathrm{Rb}_{2} \mathrm{MnCl}_{4}\left(\mathrm{H}_{2} \mathrm{O}\right)_{2}$. Acta Chem. Scand. 1964, 18, 2085.

[98] J. D. Martin, R. F. Hess, P. D. Boyle, Synthesis of [ $\mathrm{NH}_{4}$ ] $\mathrm{MnCl}_{2}(\mathrm{OAC})$ and $\left[\mathrm{NH}_{4}\right]_{2} \mathrm{MnCl}_{4}\left(\mathrm{H}_{2} \mathrm{O}\right)_{2}$ by solvothermal dehydration and structure/property correlations in a one-dimensional antiferromagnet. Inorg. Chem. 2004, 43, 3242.

[99] S. Pagola, K. T. Trowell, K. C. Havas, Z. D. Reed, D. G. Chan, M. J. Van Dongen, G. C. DeFotis, Crystal structures of manganese and cobalt dichloride monohydrate and deuteration effects on magnetic behavior. Inorg. Chem. 2013, 52, 13341.

[100] W. Clegg, Hexaamminechromium(III) aquapentachloromanganate(II). Acta Crystallogr. B 1978, 34, 3328.

[101] J. A. Alonso, M. J. Martínez-Lope, M. T. Casais, M. T. Fernández-Díaz, Evolution of the Jahn-Teller distortion of $\mathrm{MnO}_{6}$ octahedra in $R \mathrm{MnO}_{3}$ perovskites ( $R=\mathrm{Pr}, \mathrm{Nd}, \mathrm{Dy}, \mathrm{Tb}, \mathrm{Ho}, \mathrm{Er}, \mathrm{Y}$ ): a neutron diffraction study. Inorg. Chem. 2000, 39, 917.

Supplementary Material: The online version of this article offers supplementary material (https://doi.org/10.1515/zkri-2018-2088). 